INSTITUTO DE PESQUISAS ENERGÉTICAS E NUCLEARES

AUTARQUIA ASSOCIADA À UNIVERSIDADE DE SÃO PAULO

\title{
UTILIZAÇÃO DE RESÍDUOS DE CATALISADOR (ECAT) E CINZAS DA CASCA DE ARROZ (CCA) NA ELABORAÇÃO DE VIDROS SILICATOS SODA-CAL DESTINADOS A EMBALAGEM
}

\section{MARIANA SILVA DE ARAUJO}

\author{
Dissertação apresentada como parte dos \\ requisitos para obtenção do Grau de \\ Mestre em Ciências na Área de \\ Tecnologia Nuclear - Materiais. \\ Orientador: \\ Dr. Luis Antonio Genova
}

Versão Corrigida

São Paulo

2016 


\section{Dedicatória}

Dedico este trabalho ao Prof. Dr. José Roberto Martinelli (in memorian) e ao meu avô $1^{\circ}$ Sg. Antonio Lourenço de Araujo (in memorian), ambos imprescindíveis para a realização deste trabalho e uma lição de paixão e disciplina que jamais deve ser esquecida. 


\section{Agradecimentos}

Ao Prof. Dr. José Roberto Martinelli, pela orientação e inspiração.

Ao Dr. Ulisses Soares do Prado e ao Prof. Dr. Luis Antonio Genova, pelos ensinamentos e parceria.

Aos ensinadores e docentes do IPEN pelo apoio e estrutura.

Ao CNPQ, pela bolsa de Mestrado.

Aos colegas de laboratório Eraldo, Juliana, Danilo e Ana Paula, pela convivência e amizade.

À Marilene e ao Eguiberto, pela preocupação e apoio.

Aos colaboradores do LPCM da FATEC-SP, Dra. Vanessa, Dr. Davinson, Dr. Thiago e Dr. Diego pela disposição e ajuda de sempre.

Aos meus pais, irmão e família, por tudo.

Ao meu avô Antonio Lourenço de Araujo, meu maior motivo de continuar motivada, focada e disciplinada.

Ao meu noivo pela paciência e dedicação e compreensão.

Aos meus amigos Caroline, Juliana, Jeferson, André, Agatha, Ana, Lucas, Viviane, Renata, Amanda e Giovana, pela amizade e incentivo.

E a todos aqueles que de alguma forma contribuíram para que esta etapa fosse concluída. 
"No meio da dificuldade encontra-se a oportunidade. " Albert Einstein 


\title{
UTILIZAÇÃO DE RESÍDUOS DE CATALISADOR (ECAT) E CINZAS DA CASCA DE ARROZ (CCA) NA ELABORAÇÃO DE VIDROS SILICATOS SODA-CAL DESTINADOS A EMBALAGEM
}

\begin{abstract}
Resumo
Estudo realizado acerca da utilização de dois resíduos sólidos industriais (RSI) gerados em grande quantidade no Brasil, na obtenção de vidros soda-cal destinados à produção de embalagens. Os resíduos avaliados foram a cinza de casca de arroz (CCA) e resíduo do catalisador usado das unidades de Craqueamento Catalítico Fluido das Petroquímicas (ECAT), ambos podem ser classificados como resíduos sólidos de classe II de acordo com a norma NBR 10.004. Esta nova proposta para destinação desses resíduos é uma alternativa às atuais disposições, buscando não apenas minimizar os impactos ambientais gerados, mas também a valorização dos mesmos como matérias-primas. Para a produção das amostras, além da utilização dos RSIs, foram também utilizados óxidos fundente $\left(\mathrm{Na}_{2} \mathrm{CO}_{3}\right)$ e estabilizante $(\mathrm{CaO})$. Os resultados obtidos demonstraram que ambos podem ser usados como recebidos (sem tratamento prévio) substituindo matérias-primas importantes, fontes de $\mathrm{Al}_{2} \mathrm{O}_{3}$ e $\mathrm{SiO}_{2}$, necessárias para a formação de vidros. As amostras obtidas apresentaram a cor âmbar devido a presença de níquel (íons $\mathrm{Ni}^{2+}$ ) proveniente do ECAT e transmitância óptica de $18 \%$. Estas, ainda demonstraram boa homogeneidade, i.e., ausência de bolhas e estriais e, resistências hidrolíticas média de $1,33 \times 10^{-8} \mathrm{~g} / \mathrm{cm}^{2}$.dia (superior à um vidro comercial de composição semelhante) de acordo com a ISO695-1984. O vidro obtido é adequado para aplicações que exigem baixa transmitância como embalagens de vidros em geral, os quais não requerem perfeita visibilidade e transparência. O teor de incorporação na composição final das amostras foi de aproximadamente $78 \%$ em massa.
\end{abstract}




\title{
USE OF RICE RUSK ASH AND SPENT CATALYST AS A SOURCE OF RAW MATERIAL FOR THE PRODUCTION AND CHARACTERIZATION OF SODA-LIME SILICATE GLASSES DESTINED FOR PACKAGING
}

\begin{abstract}
In this study, the use of two industrial solid wastes (ISW), generated in large quantities in Brazil, were presented in production of soda-lime silicate glasses destined for packaging. The evaluated wastes were rice husk ash (RHA) and the spent catalyst at the Petrochemical Fluid Catalytic Cracking units (ECAT), both may be classified as a class II solid waste according to NBR 10.004. This new proposal for the allocation of such wastes is an alternative to current provisions, seeking not only to minimize environmental impacts, but also enrich them as raw materials. For the samples production, besides ISW were used melting oxide $\left(\mathrm{Na}_{2} \mathrm{CO}_{3}\right)$ and stabilizer oxide (CaO).The results demonstrate that both can be used in their raw form (without treatment) replacing important raw materials, sources of $\mathrm{Al}_{2} \mathrm{O} 3$ and $\mathrm{SiO}_{2}$, essential for glass formation. The samples obtained presented amber color due to the presence of nickel ( $\mathrm{Ni}^{2+}$ ion) from ECAT and $18 \%$ of optical transmittance. They also showed a good homogeneity, i.e., absence of bubbles and striae and $1,33 \times 10^{-8} \mathrm{~g} / \mathrm{cm}^{2}$. day of hydrolytic resistance according to ISO695-1984. Thus, the obtained glass is suitable for applications requiring low light transmittance such as colored glasses containers in general, which does not require perfect visibility and transparency. The incorporation in the final composition was approximately $78 \%$ in mass.
\end{abstract}




\section{SUMÁRIO}

INTRODUÇÃO

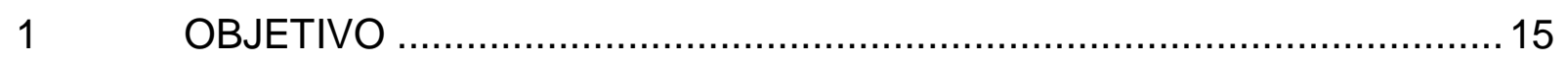

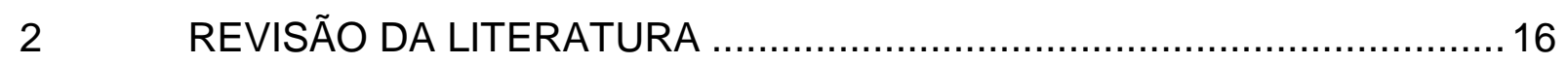

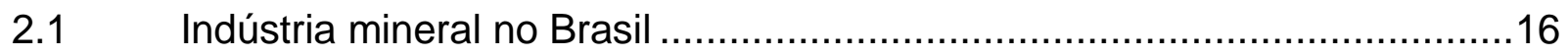

2.2 Política Nacional de Resíduos Sólidos (PNRS) …………………….........17

2.3 Resíduos sólidos industriais ..............................................................18

2.3.1 Cinza da casca de arroz (CCA) .......................................................18

2.3.2 Catalisador exaurido das Petroquímicas (ECAT) .....................................19

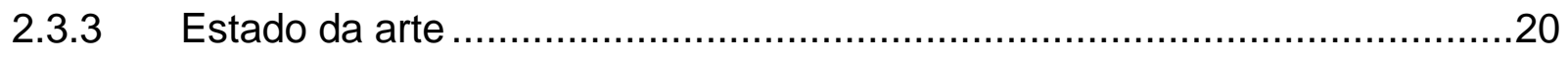

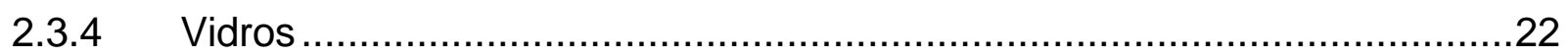

2.3.4.1 Histórico e definição ...............................................................................22

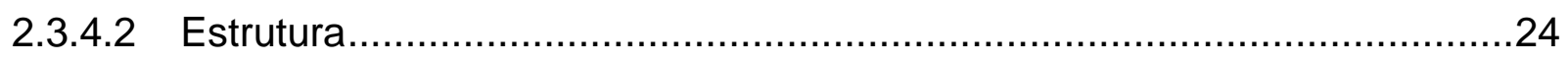

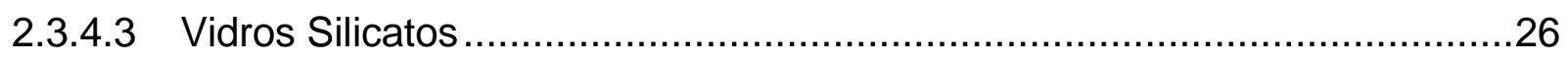

2.4 A influência da viscosidade na formação de vidros silicatos ........................27

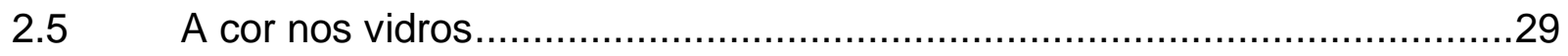

2.6 Durabilidade Química ............................................................................

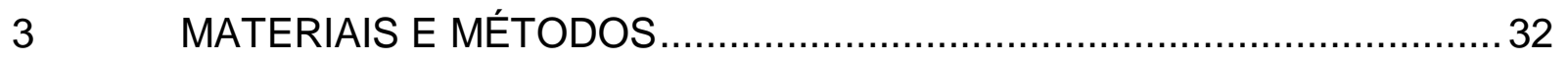

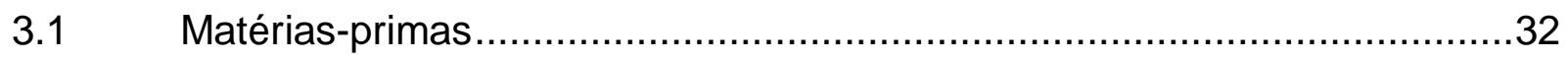

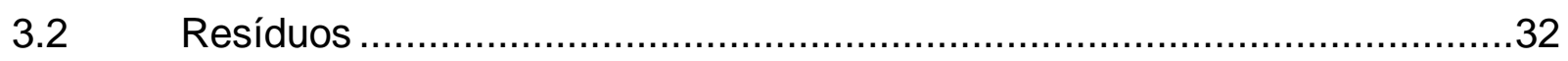

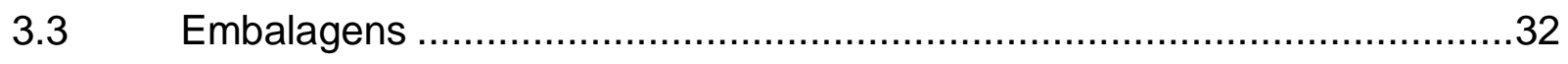

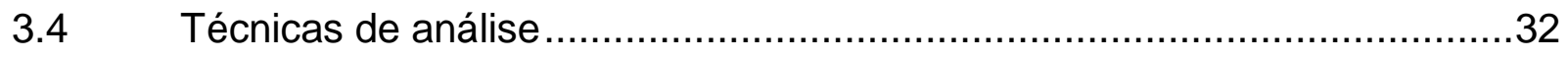

3.4.1 Espectrometria por Fluorescência de Raios- X (FRX) ………………......33

3.4.2 Espectrometria por Difração de Raios-X (DRX) .........................................34

3.4.3 Diâmetro médio equivalente (distribuição granulométrica por dispersão a laser) 34

3.4.4 Análise morfológica por Microscopia Eletrônica de Varredura (MEV) ..........35 
3.4.5 Análise de defeitos volumétricos e homogeneização por Microscopia Óptica (MO) 38

3.4.6 Análise Térmica Diferencial (ATD) ................................................... 40

3.4.7 Espectrometria de Transmitância e Absorbância no UV-VIS ......................41

3.4.8 Medidas de cor no sistema CIE ............................................................

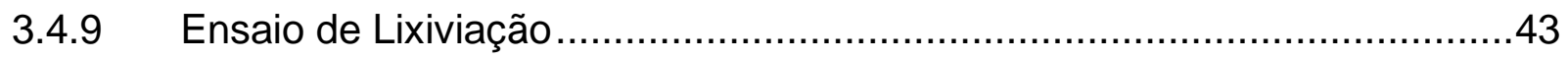

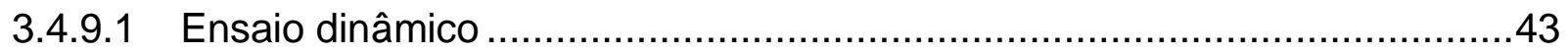

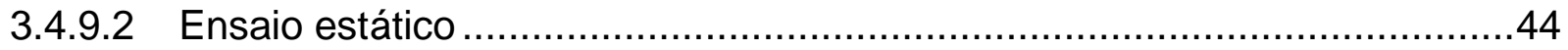

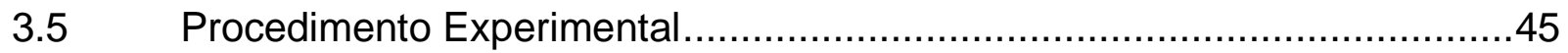

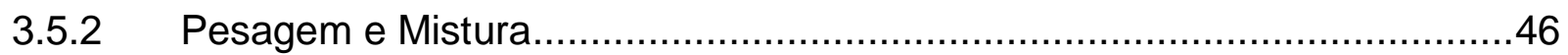

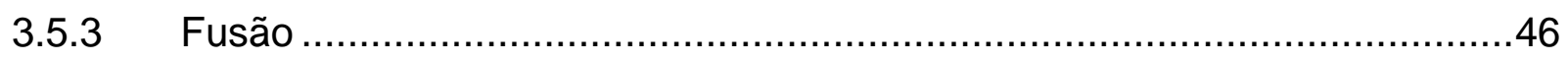

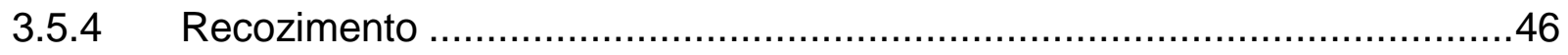

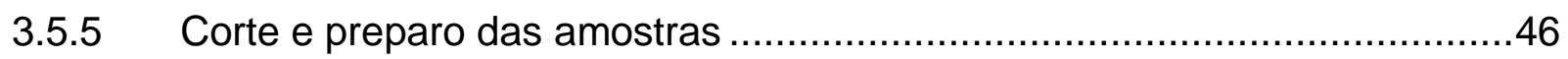

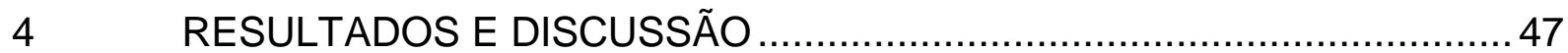

4.1 Caracterização das matérias-primas ……..........................................47

4.1.1 Cinza da Casca de Arroz (CCA) ……................................................

4.1.2 Resíduo de catalisador exaurido (ECAT) ............................................50

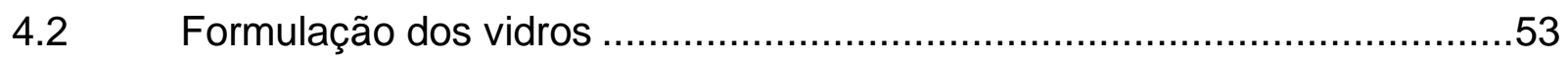

4.3 Resultados obtidos nas primeiras fusões ............................................54

4.4 Caracterização dos vidros estudados .......................................................

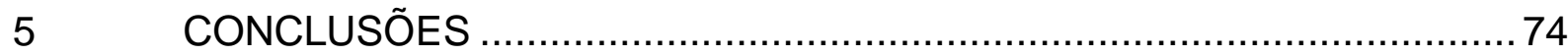

$6 \quad$ SUGESTÕES PARA TRABALHOS FUTUROS …................................. 75

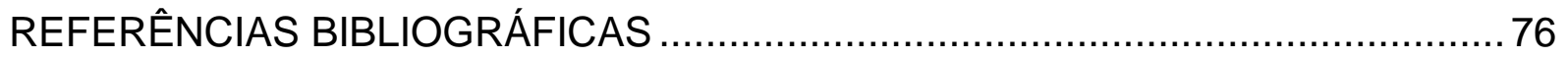




\section{ÍNDICE DE FIGURAS}

Figura 1. Representação bidimensional do arranjo simétrico de um cristal (à esquerda) e de uma rede de vidro, caracterizada pela ausência de periodicidade (à direita) [21].

Figura 2. Mudança de volume durante o resfriamento de um líquido (adaptado [25]).

Figura 3. Curvas características da viscosidade em função da temperatura para os vidros soda-cal [30]. 28

Figura 4. Representação esquemática dos componentes de um microscópia eletrônico de varredura. Fonte: Adaptado pelo autor [40]. 36

Figura 5. Interação elétron-amostra durante a análise por microscopia eletrônica de varredura. Fonte: Adaptado pelo autor [40]. .37

Figura 6. Diagrama esquemático de um microscópio óptico. Fonte: Adaptada pelo autor [40]. 39

Figura 7. Diagrama CIE de coordenadas colorimétricas [43]..... 42

Figura 8. Esquema ilustrativo do procedimento experimental adotado. .45

Figura 9. Macrografia do resíduo cinza da casca de arroz (CCA). 47

Figura 10. (a) e (b) Micrografias da cinza da casca de arroz (CCA) obtidas por microscopia eletrônica de varredura. 48

Figura 11. Distribuição granulométrica da cinza da casca de arroz (CCA) obtida por espalhamento a laser. 48

Figura 12. Análise obtida por difração de raios-X da cinza da casca de arroz (CCA).

Figura 13. Macrografia do resíduo de catalizador exaurido (ECAT). .50

Figura 14. (a) e (b) Micrografias do resíduo de catalizador exaurido (ECAT) obtidas por microscopia eletrônica de varredura (MEV).

Figura 15. Distribuição granulométrica do resíduo de catalizador exaurido (ECAT) obtida por espalhamento a laser.

Figura 16. Análise obtida por difração de raios- $X$ do resíduo de catalizador exaurido (ECAT). .52 
Figura 17. Amostra obtida a partir da segunda fusão. .........................................56

Figura 18. Imagem obtida por microscopia óptica. ............................................57

Figura 19. (a) e (b) Imagens obtidas por microscopia óptica.................................57

Figura 20. Amostra obtida a partir da terceira fusão..............................................58

Figura 21. (a) e (b) Imagens obtidas por microscopia óptica.................................58

Figura 22. Imagem obtida por microscopia óptica...............................................59

Figura 23. Amostra obtida a partir da quarta fusão. .............................................59

Figura 24. Imagem obtida por microscopia óptica. …….........................................6

Figura 25. (a) e (b) Imagens obtidas por microscopia óptica.................................60

Figura 26 (a) e (b). Amostras 1CCA-ECAT (a) e 2CCA-ECAT (b)..........................63

Figura 27. Análise obtida por difração de raios-X do vidro 1CCA-ECAT. ...................63

Figura 28. Análise térmica diferencial do vidro comercial (Vidro 1), 2CCA-ECAT e 1CCA-ECAT.

Figura 29. Gráfico da perda de massa durante o ensaio de resistência hidrolítica....65 Figura 30. Gráfico da Razão de dissolução média em função dos dias das amostras 1CCA-ECAT, 2CCA-ECAT e Comercial (Vidro 1) do início ao fim do ensaio de lixiviação. 66

Figura 31. Diagrama comparativo contendo a composição química relativa da amostra 1CCA-ECAT antes e após o ensaio de lixiviação.

Figura 32. Diferença obtida entre as composições Pré e Pós lixiviação da amostra 1CCA-ECAT.

Figura 33. Imagens obtidas por microscopia óptica. (a) Amostra 1CCA-ECAT antes do ensaio de lixiviação; (b) Amostra 1CCA-ECAT após o ensaio de lixiviação. ........68 Figura 34. (a) e (b) Imagens obtidas por microscopia óptica da amostra 1CCA-ECAT antes (a) e após (b) o ensaio de resistência hidrolítica. 69

Figura 35. (a) e (b) Imagens obtidas por microscopia óptica da amostra 1CCA-ECAT antes (a) e após (b) o ensaio de resistência hidrolítica.

Figura 36. Espectros de absorbância óptica das amostras comercial e 1CCA-ECAT.

Figura 37. Espectros de transmitância óptica das amostras comercial e 1CCA-ECAT. 
Figura 38. Coordenadas colorimétricas no sistema CIE..................................... 72 Figura 39. Macrografia das amostras 1CCA-ECAT, 2CCA-ECAT e Comercial

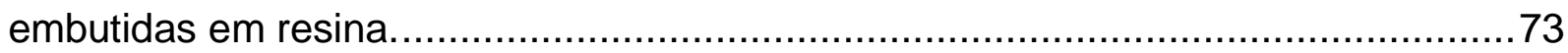




\section{ÍNDICE DE TABELAS}

Tabela 1. Principais empresas mineradoras de areia industrial no Brasil .................17

Tabela 2. Composições de vidros Soda-Cal mais utilizadas (\% em massa)..............27 Tabela 3. Variações de coloração de metais de transição em vidros soda-cal e outros vidros. 29

Tabela 4. Coloração correspondente à interação do íon de metal de transição com a matriz. 30

Tabela 5. Composição química em porcentagem em massa do resíduo CCA obtida pela técnica de fluorescência de raios- $X$. 49 Tabela 6. Composição química em porcentagem em massa do resíduo de catalizador exaurido (ECAT) obtida por fluorescência de raios- $X$. .51

Tabela 7. Composição química em porcentagem em massa obtida por fluorescência de raios- $X$ dos vidros de perfume. .53 Tabela 8. Composição química em porcentagem em massa calculada do vidro a ser estudado. .54

Tabela 9. Resumo das primeiras tentativas de fusão. .55 Tabela 10. Composição química (em \% em massa) das tentativas de fusão obtidas por fluorescência de Raios-X. 61

Tabela 11. Composição química obtida por fluorescência de raios-X das amostras obtidas (\% em massa). 62

Tabela 12. Valores atribuídos à temperatura de transição vítrea obtidos a partir da análise térmica diferencial. 64

Tabela 13. Razões de dissolução média das amostras 1CCA-ECAT, 2CCA-ECAT e Comercial (Vidro 1), após 14 dias imersos em água destilada à $90^{\circ} \mathrm{C}$. 66 


\section{INTRODUÇÃO}

O aumento da produtividade de recursos ${ }^{1}$ é uma preocupação atual na qual se faz cada vez mais necessário a substituição de materiais dispendiosos e escassos por materiais mais baratos, eficientes e que promovam alternativas aos processos produtivos, visando um crescimento orgânico e sustentável da produção [1].

Tal aumento pode surgir da simples combinação da tecnologia de informação, ciência dos materiais e compreensão da biologia com a tecnologia e infraestrutura industriais.

A possibilidade de crescimento da produtividade dos recursos representa uma alternativa para acompanhar o aumento da demanda mundial, uma vez que a elevação na riqueza em países em desenvolvimento, como a China e Índia, abrem portas para preocupações, pois, afinal, bilhões de pessoas em breve terão uma renda para consumir muito mais recursos do que já tiveram antes. Neste contexto, a população mundial está prestes a colocar uma demanda sem precedentes sobre os recursos naturais justamente quando os mesmos estão minguando [1]

Avaliando as oportunidades e mudanças do uso de recursos em novas tecnologias aplicadas na indústria, podemos concluir que estamos no limiar da maior oportunidade de negócios em um século. De forma que ao invés de enfrentar uma crise proveniente da escassez de recursos não renováveis, temos em mãos a possibilidade de reformular a economia do mundo e criar margem para lucros consideráveis. Para tal, os processos usuais exigiriam uma nova abordagem de gestão, unindo as cadeias produtivas em uma condição vantajosa.

O comércio brasileiro de resíduos sólidos industriais (RSI) movimenta em torno de $\mathrm{R} \$ 250$ milhões de reais por ano, quando possui um potencial estimado para chegar a $\mathrm{R} \$ 1$ bilhão por ano [2]. Em decorrência da má utilização deste potencial, na

\footnotetext{
${ }^{1} \mathrm{~A}$ produtividade é o quociente entre quantidade de bens/serviços gerados e insumos utilizados. Em outras palavras, é a quantidade de bens e serviços obtidos com a utilização de uma unidade de insumo. Neste caso, a produtividade dos recursos refere-se a quantidade de bens produzidos através da utilização de uma unidade de recurso. Portanto, aumento na produtividade de recursos é um aumento na quantidade marginal produzida, dado a utilização de uma unidade de recurso.
} 
literatura brasileira há uma vasta gama de resíduos sólidos industriais que não possuem um gerenciamento adequado.

Em suma, a recuperação dos RSI e sua respectiva incorporação nos processos produtivos permitem não apenas minimizar os impactos ambientais, mas sua valorização e comercialização no mercado como matéria-prima.

Neste trabalho, serão estudados os RSI que podem ser usados como matériasprimas para a produção de vidros destinados à embalagem: a cinza da casca de arroz (CCA) proveniente do ciclo de industrialização do arroz e o resíduo dos catalisadores utilizados nas unidades de Craqueamento Catalítico Fluido das Petroquímicas (ECAT). Ambos os resíduos podem ser classificados como resíduos sólidos classe II de acordo com a NBR 10.004 [3]. 


\section{OBJETIVO}

Este trabalho tem como objetivo a elaboração e caracterização de vidros silicatos soda-cal utilizados em embalagens, a partir dos resíduos sólidos industriais cinza da casca de arroz (CCA) e resíduos de catalizador exaurido (ECAT), e a posterior comparação de propriedades obtidas com vidros comerciais. 


\section{REVISÃO DA LITERATURA}

\subsection{Indústria mineral no Brasil}

O termo areia industrial geralmente é utilizado para designar areias silicosas empregadas, em estado natural ou beneficiadas, na fabricação de vidro e outros produtos cerâmicos. Trata-se de um conceito bastante amplo e compreende areias com elevado conteúdo de quartzo, com especificações definidas de acordo com a aplicação.

Atualmente, a produção e consumo de areia industrial no Brasil no setor vidreiro já ultrapassou 1,75 milhões de toneladas anuais, uma vez que representa cerca de $24 \%$ da demanda [4].

No Brasil, a demanda concentra-se na região Sudeste, com destaque para o estado de São Paulo, que representa mais de 50\% de consumo no país. Entretanto, devido ao deslocamento de alguns empreendimentos do setor para o Rio Grande do Sul e Santa Catarina, fazem desta, uma área com crescimento expressivo, obtendo um aumento de $13,05 \%$ para 19,68\% em apenas seis anos (2004-2010) [4].

Devido à insuficiência de dados fornecidos pelo Departamento Nacional da Produção Mineral (DNPM) [5] em seu Anuário Mineral brasileiro, último publicado em 2010, autores [6] realizaram uma projeção estimando a produção de areia industrial até 2030 com base na variação do Produto interno Bruto (PIB), indicando que mesmo em um cenário frágil, com o país enfrentando crise econômica, instabilidade e retrocesso, ainda haverá um aumento significativo na demanda. E ainda, mesmo o país possuindo reserva suficiente para extração e beneficiamento para atender tal demanda, a aglomeração dos polos fará com haja uma exaustão das reservas locais, favorecendo o deslocamento dos empreendimentos e a descentralização da extração.

Além disso, existem aspectos ambientais envolvidos nesta operação que geram impactos negativos significativos que, nem sempre são fiscalizados corretamente. 
A maioria das empresas do ramo é de médio ou grande porte e $65 \%$ são empresas multinacionais que utilizam a areia industrial como matéria-prima para produção de produtos finais. Abaixo, na Tabela 1, podem-se observar as principais empresas produtoras no setor.

Tabela 1. Principais empresas mineradoras de areia industrial no Brasil.

\begin{tabular}{l|c|c}
\hline \multicolumn{1}{c|}{ Empresa } & Estado $^{1}$ & Participação (\%) $^{2}$ \\
\hline Mineração Jundu Ltda. & MG,SC,SP & 45,23 \\
\hline Mineração Descalvado Ltda. & SP & 10,36 \\
\hline Unimin do Brasil Ltda. & SC & 5,73 \\
\hline Mineração Veiga Ltda. & SC & 4,74 \\
\hline Saint-Gobain do Brasil Ltda. & MG, SP & 4,69 \\
\hline Empresa Brasileira do Quartzo Ltda. & BA, MG & 2,89 \\
\hline Empresa de Mineração Elias João Jorge Ltda. & SP & 2,58 \\
\hline Votorantim Cimentos N/NE S.A. & CE, PB & 2,45 \\
\hline Darcy R.O. e Silva \& Cia. Ltda. & SP & 2,33 \\
\hline Curupi Mineração S.A. & RJ & 2,01 \\
\hline
\end{tabular}

'Unidade da Federação onde ocorreu a comercialização e/ou consumo da produção bruta e/ou beneficiada. 2Participação percentual da empresa no valor total da comercialização da substância. Fonte: Departamento Nacional da Produção Mineral (2010) [5].

Além da areia industrial, são utilizadas também para a fabricação de vidros outras matérias-primas, como o calcário, barrilha e feldspato, que correspondem a um consumo anual superior a 240, 300 e 30 mil toneladas respectivamente [6].

\subsection{Política Nacional de Resíduos Sólidos (PNRS)}

Em 2010, a partir da Lei oㅜ 12.305, foi instituída a Política Nacional de Resíduos Sólidos (PNRS). Tal política contém instrumentos importantes para permitir o avanço 
necessário diante dos principais problemas ambientais, sociais e econômicos relacionados ao gerenciamento inadequado dos resíduos sólidos em geral [7].

O PNRS prevê ações preventivas e a redução na geração de resíduos, propondo práticas sustentáveis associadas a padrões que possam potencializar a reciclagem e reutilização de resíduos nos processos, agregando valor econômico aos mesmos. E ainda, em um pior cenário, assegurar a destinação adequada ambientalmente aos rejeitos que não podem ser reutilizados.

O plano aborda ainda o termo de "responsabilidade compartilhada" onde não só o governo, mas também os fabricantes, importadores, distribuidores, comerciantes, e o cidadão (consumidor) possuem responsabilidade sobre a gestão, Logística Reversa e pós-consumo dos resíduos gerados.

\subsection{Resíduos sólidos industriais}

\subsubsection{Cinza da casca de arroz (CCA)}

A CCA é um subproduto da queima da casca de arroz utilizada na geração de energia em termelétricas e outros processos caloríficos [8].

A casca de arroz representa o maior volume entre os subprodutos do beneficiamento do arroz, chegando, em média a $22 \%$ em peso [9]. Propiciando temperaturas de até $1000^{\circ} \mathrm{C}$ [9], é usada na alimentação de fornalhas de secadores e das autoclaves da própria indústria arrozeira.

A produção de casca de arroz no mundo chega a mais de 80 milhões por ano. Isto representa, por exemplo, na Índia, a produção de 22 milhões de toneladas anuais, gerando $200 \times 10^{9} \mathrm{MJ}$ de energia [10].

Segundo dados da CONAB da região centro-sul do Brasil, [11] referente à safra do arroz durante o período de 2014, se toda a casca de arroz disponível no país fosse queimada, a produção de cinza seria em torno de 500 mil toneladas, uma vez que representa cerca de $20 \%$ do peso da casca [9].

Entretanto, devido a uma combinação de ineficiência gerencial e insuficiência de demanda para utilização deste resíduo, atualmente é estimado que apenas $40 \%$ 
desse montante é de fato gerado anualmente, o que com certeza ainda representa uma quantidade copiosa [8].

Além de a CCA possuir a sílica, óxido formador de rede vítrea, como composto majoritário em sua composição ( 92\%), possui também teores de outros óxidos importantes na produção de vidros, como a alumina, óxido de cálcio, entre outros, podendo ainda conter reduzidas quantidades de metais e ligas.

\subsubsection{Catalisador exaurido das Petroquímicas (ECAT)}

A maior parte das refinarias brasileiras foi construída nas décadas de 1960 e 1970. Inicialmente, elas foram concebidas para processar petróleos importados, pois, na época, a produção doméstica era incipiente. Entretanto, com o aumento significativo da produção brasileira de petróleo, houve a necessidade de dispor de maior capacidade de unidades de conversão [12].

A principal unidade de conversão do refino brasileiro é o Craqueamento Catalítico Fluido (FCC). E, atualmente, existem de 14 destas unidades no país. As unidades de FCC tem a função de converter gasóleo em frações mais leves, como o gás GLP (gás de cozinha), a gasolina e o diesel. Esse tipo de unidade, se adaptados seu processo e catalisador, poderá processar cargas compostas com a adição de algumas frações residuais do refino. Nesse caso, passam a ser chamadas de unidades de RFCC.

No início da década 1980, devido ao segundo choque do petróleo que incitou o uso de energias alternativas e provocou uma recessão, o Brasil passou a ter um excesso de disponibilidade de óleo combustível. Como consequência, foi criado, então, o Programa Fundo de Barril, que visava maximizar a conversão das frações residuais do petróleo, obtendo rendimento maior de combustíveis nobres.

A adição de frações residuais à carga das unidades de FCC até então não era praticada, constituindo-se esta basicamente de gasóleo pesado de vácuo. Como existia uma folga de capacidade nas unidades de FCC, essas naturalmente foram escolhidas para processar o excesso de resíduo de vácuo. 
A Petrobras atualmente possui posição de liderança nessa prática, adicionando um teor de aproximadamente $30 \%$ dos resíduos [12].

O ECAT, nome dado ao catalizador exaurido, é o resíduo resultante da substituição contínua de catalisadores no processo nas unidades de FCC. Esta prática é necessária quando sua capacidade de catálise diminui devido à impregnação de metais oriundos do petróleo.

O ECAT é composto majoritariamente por sílica e alumina, contendo ainda, lantânio presente no catalisador virgem e alguns metais, principalmente níquel e vanádio, que são incorporados ao catalisador durante o processo de catalise.

No Brasil existem três unidades de RFCC que disponibilizam o ECAT, que juntas somam cerca de 25 mil toneladas do resíduo por ano [13].

Elas foram implantadas com a aquisição de tecnologias de licenciadores internacionais, exceto as três últimas unidades construídas, destinadas ao processamento de cargas que contêm resíduo, cujos projetos de engenharia básica e executiva foram totalmente nacionais.

\subsubsection{Estado da arte}

Apesar de haver muitos trabalhos reportados com métodos de incorporação envolvendo tais resíduos, principalmente a CCA, as que são postas em prática ainda não representam uma porcentagem considerável frente à geração destes resíduos, de forma que o volume reaproveitado ainda é muito baixo diante do que é gerado [8].

Estudos realizados desde a década 1920 mostram tentativas de substituição destes resíduos nos processos, principalmente de cerâmicas tradicionais, isto sem alterar e/ou prejudicar as propriedades do produto final [9].

Alternativas para a aplicabilidade da CCA foram apresentadas tais como a produção de carbeto de silício, extração de sílica pura a partir do beneficiamento da CCA, utilização desta como carga em polímeros, produção de cimentos e uso em concretos, utilização como adsorventes, suporte de catalisadores metálicos, síntese de zeólitas e incorporação em diferentes tipos de silicatos [9]. 
Além destas propostas, foi realizado um estudo das propriedades estruturais e ópticas de vidros do sistema xBaO: $(80-x) \mathrm{B}_{2} \mathrm{O}_{3}: 20 \mathrm{CCA}$ com a incorporação de $20 \%$ em massa de CCA, utilizando o resíduo após recozimento a $1100^{\circ} \mathrm{C}$ e patamar 5 horas como fonte de sílica [14].

Foram apresentados resultados satisfatórios para a incorporação de CCA previamente beneficiada, com recozimento a $1000^{\circ} \mathrm{C}$ e patamar 5 horas, na produção de vidros coloridos dopados com terras raras. A composição adotada foi (55-x) $\mathrm{SiO}_{2}: 13 \mathrm{~B}_{2} \mathrm{O}_{3}: 1 \mathrm{Al}_{2} \mathrm{O}_{3}: 6.3 \mathrm{CaO}: 4.5 \mathrm{BaO}: 0.2 \mathrm{Sb}_{2} \mathrm{O}_{3}: 20 \mathrm{Na}_{2} \mathrm{O}$, onde toda a sílica foi substituída pela CCA beneficiada e $\mathrm{x}$ representa a porcentagem molar do dopante [15].

O ECAT foi objeto de estudo como substituto do caulim na formulação das fritas cerâmicas [16]. E ainda avaliado quanto sua influência e ação no processamento, além de características estéticas [13].

De mesmo modo, foram ainda reportados estudos utilizando tanto o ECAT como a CCA na produção de geopolímeros (materiais artificiais obtidos por ativação alcalina de materiais alumino-silicatados) devido à elevada reatividade e atividade pozolânica de ambos resíduos [[17]-[19]].

Atualmente, empresas multinacionais têm apresentado interesse nas pesquisas desenvolvidas, com o intuito de aplicá-las em escala industrial através da incorporação de novos recursos (matérias-primas). Um exemplo é o da empresa italiana Pirelli que montou uma fábrica exclusivamente para o beneficiamento da CCA para a obtenção de sílica pura. Em uma nota publicada em janeiro de 2015, a empresa alega que já ultrapassou a marca de um milhão de pneus produzidos com a incorporação de renováveis, atingindo uma produção em torno de 100 toneladas de sílica pura por mês [20].

Entretanto, apesar de estes números serem representativos na escala de produção, a quantidade de CCA reaproveitada neste processo não chega a $1 \%$ de sua estimativa de geração anual. 
$\mathrm{Na}$ fabricação dos vidros pode ser empregado um grande número de matérias-primas naturais e sintéticas, tornando-o uma alternativa promissora para utilização de RSIs, os quais apresentam dificuldade de serem reaproveitados nos processos convencionais em grande porcentagem.

Em alternativa, os vidros com sua estrutura amorfa, permitem a solubilização de grandes quantidades de diferentes elementos. E tendo posto que sua base e principal componente para fabricação é a sílica, a expectativa de incorporação dos resíduos neste processo é de no mínimo 60\%.

\subsubsection{Vidros}

\subsubsection{Histórico e definição}

O primeiro contato do homem com o vidro foi a observação deste material através da sua ocorrência natural, formado a partir de situações críticas, como por exemplo, erupções vulcânicas, durante as quais ocorrem a fusão de rochas seguida de uma solidificação extremamente rápida.

Tais vidros, por ocorrerem naturalmente, não possuem um padrão com relação à sua composição, podendo conter teores de óxidos abundantes (como a sílica) ou até mesmo de metais de transição em geral.

Apesar da falta de conhecimento e domínio das técnicas de fabricação, sua utilização data desde a idade da pedra (8000 A.C.). E, até os últimos 300 anos, não havia um entendimento específico sobre os fenômenos envolvidos em sua formação [21].

Sua definição é complexa e discutida até os dias atuais principalmente por existirem inúmeras técnicas para sua obtenção e uma gama de composições, que fogem cada vez mais do clássico. 
Inicialmente, o vidro era definido através de conceitos básicos de viscosidade, sendo "um produto inorgânico fundido, que atinge por resfriamento uma condição rígida, sem que ocorra cristalização" [22].

Entretanto, com o avanço tecnológico e a busca por uma definição mais complexa, em 1932, Zachariasen, através do renomado artigo 'The Atomic Arrangement in Glass', traduzido como 'O Arranjo Atômico em Vidros', propôs que o arranjo da rede vítrea seria composto por "uma rede tridimensional estendida a qual apresenta ausência de simetria e periodicidade" [23].

A Figura 1, representa a proposta de Zachariasen visualizando a diferença bidimensional entre uma rede de um cristal e de um vidro.
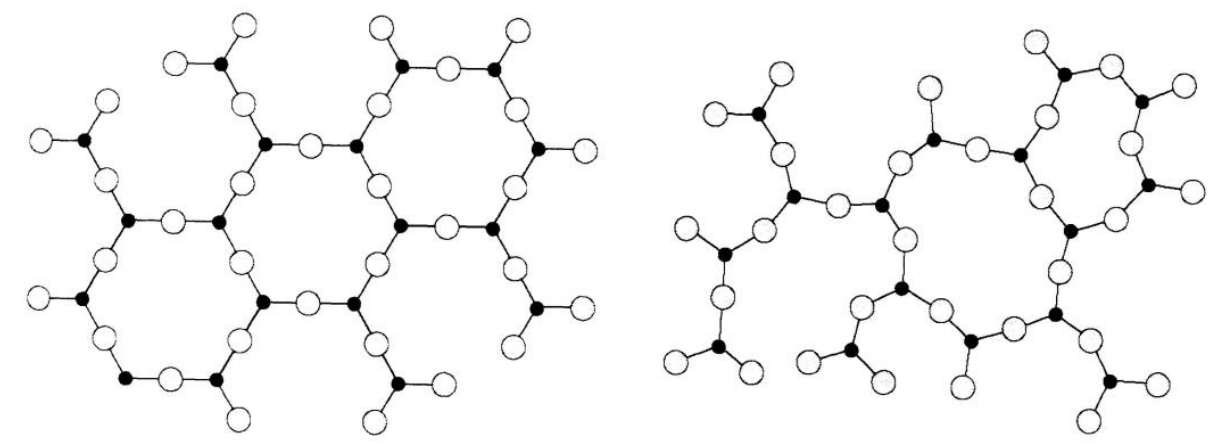

Figura 1. Representação bidimensional do arranjo simétrico de um cristal (à esquerda) e de uma rede de vidro, caracterizada pela ausência de periodicidade (à direita) [21].

Gupta ainda, em seu artigo 'Non-Crystalline Solids: Glasses and Amorphous Solids' expôs a diferença entre materiais não-cristalinos e sólidos amorfos e que estes, não devem ser encarados como sinônimos [24]. Afirmando que por questões termodinâmicas, a definição correta seria que 'um vidro é um sólido não-cristalino, portanto, com ausência de simetria e periodicidade translacional, que exibe o fenômeno de transição vítrea" e, assim como Zachariasen, pode ser obtido "a partir de qualquer material inorgânico, orgânico ou metálico e formado através de qualquer técnica de preparação" [[23]-[24]]. 
Desta forma, atualmente utiliza-se a definição de que "vidro é um sólido amorfo com ausência completa de ordem a longo alcance e periodicidade, exibindo uma região de transição vítrea. Qualquer material, inorgânico, orgânico ou metal, formado por qualquer técnica, que exibe um fenômeno de transição vítrea é um vidro". [22]

\subsubsection{Estrutura}

Dentre as técnicas de obtenção de vidros, a mais utilizada é a por fusão, seguida de um resfriamento rápido, onde há uma variação considerável do volume.

A Figura 2 representa tal variação em relação à temperatura, seus estados físicos e a diferença entre a obtenção de um sólido cristalino e o vidro.

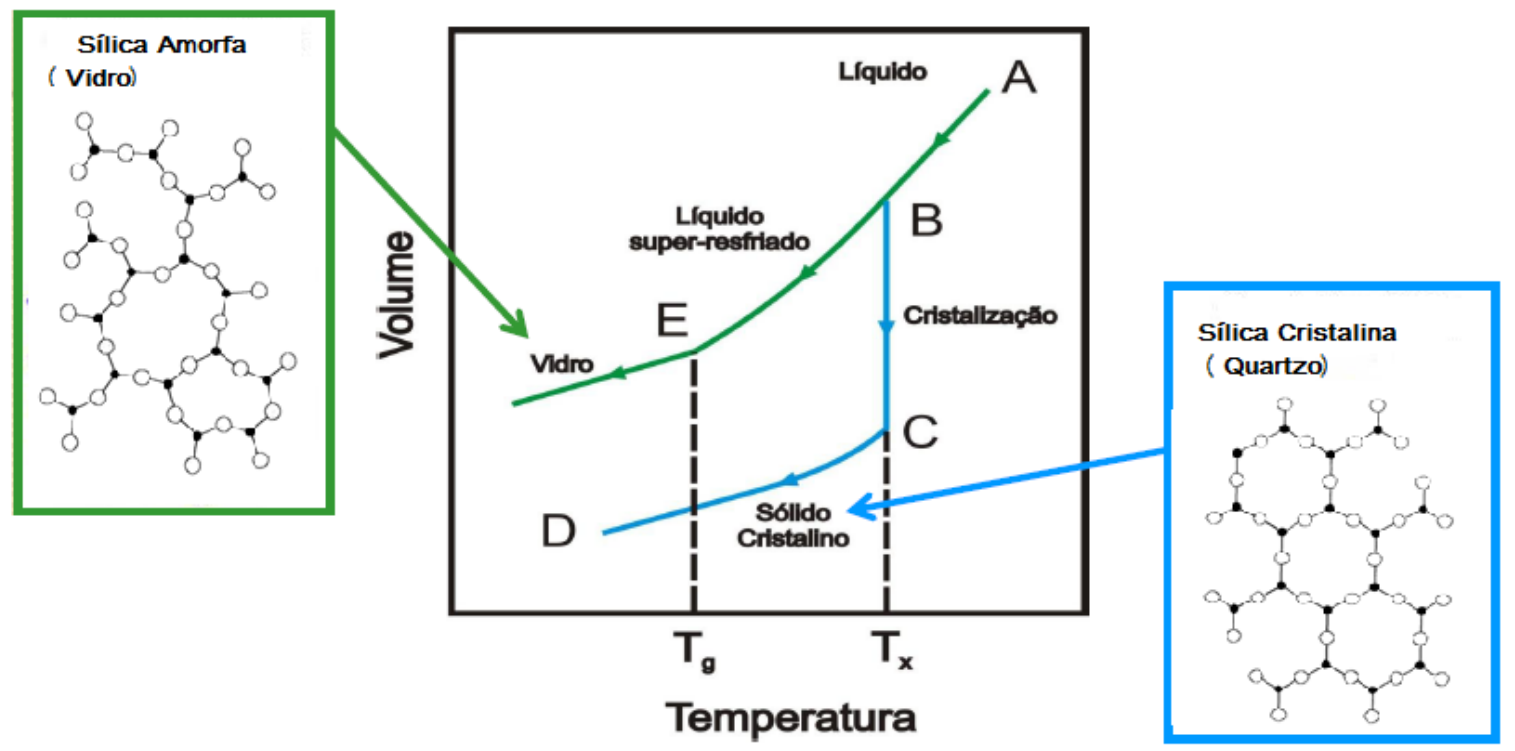

Figura 2. Mudança de volume durante o resfriamento de um líquido (adaptado [25]).

A Figura 2 é um diagrama da variação da temperatura em relação ao volume, para a formação de vidros, cristais e líquidos. Onde Tx é a temperatura de fusão cristalina e $\mathrm{Tg}$, a temperatura de transição vítrea.

Para ocorrer a cristalização é preciso certo tempo para que os átomos se organizem e formem uma rede tridimensional periódica. $O$ resfriamento rápido do 
vidro serve para que não haja tempo suficiente para tal organização, passando assim pelo estado metaestável, região de equilíbrio termodinâmico onde pode ocorrer a cristalização, fazendo com que os átomos percam energia cinética antes de se ordenarem. Não ocorrendo a cristalização, o líquido continuará em seu estado metaestável até atingir a temperatura de transição vítrea $\left(\mathrm{T}_{\mathrm{g}}\right)$ [26].

A temperatura de transição vítrea é uma temperatura característica para vidros que representa 0 limite entre 0 estado vítreo e 0 viscoelástico. Apenas em temperaturas menores que a $T_{g}$ é possível obter vidros. $E$, a determinação da $T_{g}$ é importante para o recozimento dos materiais uma vez que se deve evitar valores próximos a ela para que não ocorra a cristalização.

Em contrapartida, o fato dos vidros não possuírem ordem de médio e longo alcance não significa que sua estrutura não seja bem definida.

Goldschmidt estabeleceu em seu modelo que a estrutura tetraédrica era essencial para a formação de vidros, já que naquela época eles eram feitos em sua maioria com sílica (composto tetraédrico). Assim, vidros com a fórmula geral $\mathrm{R}_{\mathrm{n}} \mathrm{O}_{\mathrm{m}}$ formam-se mais facilmente quando a razão entre os raios do cátion e do oxigênio correspondem à um número de coordenação igual a 4 [27].

Zachariasen, tentou ampliar este conceito e explicar porque alguns números de coordenação favoreciam a formação de vidros [23]. De maneira que suas conclusões foram:

- Nenhum átomo de oxigênio deveria estar ligado a mais do que dois cátions da rede;

- O número de átomos de oxigênio que circundam o cátion deve ser pequeno;

- As estruturas poliédricas formadas por estes átomos devem compartilhar somente os vértices e nunca as arestas ou faces;

- Cada poliedro deve compartilhar, pelo menos, três vértices com outros poliedros.

Stanworth escreveu sobre vidros mistos (que possuem mais de um óxido) baseando-se na eletronegatividade dos cátions ligantes [28]. Assim, os óxidos foram classificados em três tipos de acordo com o caráter da sua ligação: 
- Formadores de Rede: Cátions que possuem ligação com caráter 50\% covalente e $50 \%$ iônica com o oxigênio.

- Modificadores de Rede: Cátions com baixa eletronegatividade, apresentando ligações com caráter fortemente covalente.

- Intermediários: Cátions que não possuem por si só características formadoras de vidros, mas que ao serem misturados à formadores típicos, podem fazer a substituição na rede.

\subsubsection{Vidros Silicatos}

Com uma ampla variação de tipos e composições para a produção de vidros, estes foram agrupados em famílias, de forma que a mais conhecida é a dos silicatos devido à sua vasta comercialização e processamento simples, além de possuírem grande estabilidade química e alta transparência.

Os vidros silicatos são ainda separados em quatro grupos principais denominados por soda-cal, borossilicatos, aluminossilicatos e silicato com chumbo.

Os vidros soda-cal são de longe os mais baratos e utilizados dentre os vidros comercializados. Produtos como vidros de janela, lâmpadas incandescentes e fluorescentes são produzidos a partir de tal composição, ajustadas conforme as aplicações específicas.

Sua considerável utilização deve-se à sua boa estabilidade química, alta resistividade elétrica e boa transmissão óptica na região do visível. Com o coeficiente de expansão térmica relativamente alto $\left(\sim 100 \times 10^{-7}{ }^{\circ} \mathrm{C}^{-1}\right)$, com relação aos outros vidros do grupo, apresenta baixa resistência ao choque térmico [[22];[26]].

Enquanto o vidro formado apenas por sílica possui propriedades desejáveis como baixo coeficiente de expansão térmica, alta resistência ao choque térmico (estabilidade dimensional) e alta resistência química, o seu alto ponto de fusão $\left(>1700^{\circ} \mathrm{C}\right)$ se torna um empecilho, aumentando o custo final do produto devido à utilização de fornos específicos (altas temperaturas) e maior custo de energia. $O$ 
desenvolvimento do vidro soda-cal representa o benefício das propriedades da sílica pura juntamente com um menor custo de produção que a grande demanda exige [[22];[26]].

A adição de carbonato de sódio influencia diretamente na temperatura de fusão, diminuindo-a significativamente. Porém seu uso em excesso causa uma desestabilização da estrutura do vidro, podendo afetar entre outros fatores, sua durabilidade química. Substituindo-o em parte por carbonato de cálcio, obtêm-se propriedades aceitáveis para aplicações de consumo além de proporcionar uma temperatura de fusão em torno de $1500^{\circ} \mathrm{C}$, aproximadamente $25 \%$ menor do que a de vidros de sílica pura [[22];[26]].

$\mathrm{Na}$ Tabela 2 estão representadas as composições de vidros soda-cal mais utilizadas.

Tabela 2. Composições de vidros Soda-Cal mais utilizadas (\% em massa).

\begin{tabular}{|l|l|l|l|l|l|l|l|l|}
\hline Componentes & $\mathrm{SiO}_{2}$ & $\mathrm{Na}_{2} \mathrm{O}$ & $\mathrm{K}_{2} \mathrm{O}$ & $\mathrm{MgO}$ & $\mathrm{CaO}$ & $\mathrm{Al}_{2} \mathrm{O}_{3}$ & $\mathrm{Fe}_{2} \mathrm{O}_{3}$ & $\mathrm{SO}_{2}$ \\
\hline Janelas & 73 & 14 & - & 4 & 9 & 0.1 & 0.1 & - \\
\hline Recipientes & 74 & 13 & 0.3 & 0.2 & 11 & 1.5 & 0.04 & 0.2 \\
\hline Lâmpadas & 72 & 16 & 1 & 4 & 3 & 2 & - & - \\
\hline
\end{tabular}

Fonte: SHELBY, J.E. Introduction to Glass Science and Technology. 2 ${ }^{\circ}$ ed. Cambridge: The Royal Society of Chemistry, 2005. [22]

\subsection{A influência da viscosidade na formação de vidros silicatos}

A viscosidade é considerada uma das mais importantes propriedades para o processo de fabricação de vidros, pois, está diretamente relacionada aos parâmetros de processo, tais como, condições de fusão e temperaturas de trabalho. 
Quanto maior a viscosidade, maior o tempo necessário para a homogeneização da massa fundida, devido à falta de mobilidade dos átomos. Tal mobilidade corrobora também para a formação de defeitos volumétricos, como bolhas e estrias, visto que a liberação de gases gerados durante a fusão é comprometida [29].

Sabe-se que quanto maior o teor de sílica da composição, maior a viscosidade e a temperatura de fusão do processo. E, por este motivo, óxidos fundentes são frequentemente utilizados para diminuí-la, gerando pontes de oxigênio não ligantes, decorrentes da "quebra" da conectividade da rede, reduzindo a viscosidade [29].

A partir da Figura 3 pode-se observar uma curva característica da variação da viscosidade de um vidro soda-cal em função da temperatura.

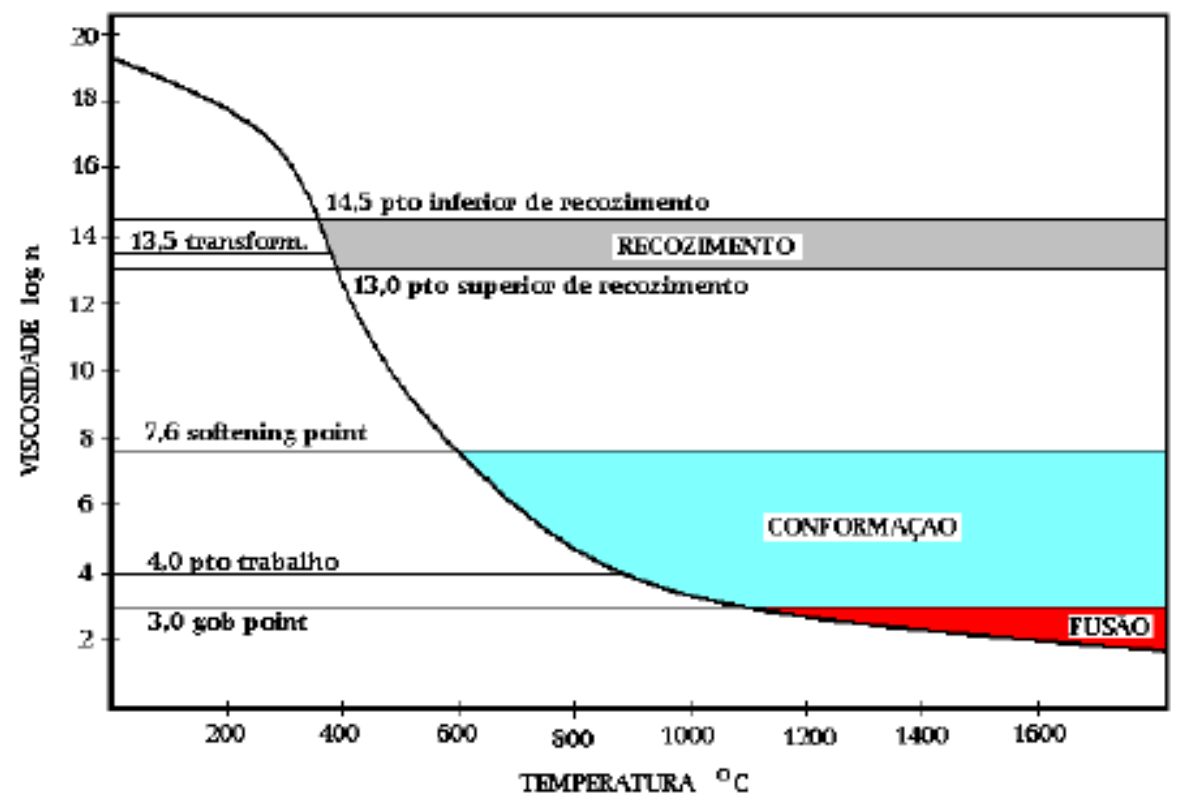

Figura 3. Curvas características da viscosidade em função da temperatura para os vidros soda-cal [30]. 


\subsection{A cor nos vidros}

Além da importância estética, a cor dos vidros pode proporcionar a filtração de certos comprimentos de onda que possam afetar de alguma maneira o produto armazenado.

A variação da cor está relacionada às matérias-primas utilizadas no processo, mais especificamente, está diretamente relacionada aos óxidos presentes em tais matérias-primas. Principalmente, os óxidos que possuem em sua fórmula íons de metais de transição, quando incorporados à rede vítrea, produzem cor na região do visível após a fusão.

A Tabela 3, apresenta algumas variações de coloração de acordo com o tipo de vidro em questão.

Tabela 3. Variações de coloração de metais de transição em vidros soda-cal e outros vidros.

\begin{tabular}{c|cc}
\hline Íon & $\begin{array}{c}\text { Coloração } \\
\text { (vidros soda-cal) }\end{array}$ & $\begin{array}{c}\text { Coloração } \\
\text { (outros vidros) }\end{array}$ \\
\hline $\mathbf{V}^{4+}$ & - & Azul \\
\hline $\mathbf{V}^{3+}$ & Amarelo-verde & - \\
\hline $\mathbf{C r}^{3+}$ & Verde & Amarelo-laranja \\
\hline $\mathbf{C r}^{2+}$ & - & Azul \\
\hline $\mathbf{M n}^{3+}$ & Roxo & - \\
\hline $\mathbf{M n}^{2+}$ & Incolor & Amarelo,Marrom \\
\hline $\mathbf{F e}^{3+}$ & Amarelo claro, Verde & incolor \\
\hline $\mathbf{F e}^{2+}$ & Verde, Azul & Amarelo, cor-de-rosa \\
\hline $\mathbf{N i}^{2+}$ & Amarelo, Marrom & roxo \\
\hline $\mathbf{C u}^{2+}$ & Azul,Verde & - \\
\hline
\end{tabular}

Fonte: NASSAU, K. The Physics and Chemistry of Color: The fifteen Causes of Color. $1^{\underline{a}}$ ed. Wiley-Interscience: p. 504. 1983.[31]

Pode observar que um mesmo elemento pode apresentar diferentes cores dependendo da matriz vítrea em questão. Entretanto, de acordo com os resultados obtidos por Salmang, em 1962, a coloração do vidro pode também ser influenciada 
pela posição na qual os metais de transição ocupam em sua estrutura, ou seja, se o íon estiver atuando como óxido formador de rede vítrea, pode manifestar uma cor diferente de quando estiver como óxido modificador.

A Tabela 4, apresenta os resultados obtidos por Salmang e indica as colorações dos vidros de acordo com o íon e sua interação com a matriz vítrea.

Tabela 4. Coloração correspondente à interação do íon de metal de transição com a matriz.

\begin{tabular}{c|cc}
\hline Íon & Formador de rede & Modificador de rede \\
\hline $\mathbf{V}^{5+}$ & Incolor a amarelo & - \\
\hline $\mathbf{V}^{4+}$ & - & Azul \\
\hline $\mathbf{V}^{3+}$ & - & Verde \\
\hline $\mathbf{C r}^{3+}$ & - & Verde \\
\hline $\mathbf{C u}^{2+}$ & Marrom-amarelado & Azul \\
\hline $\mathbf{C u}^{1+}$ & - & $\begin{array}{c}\text { Incolor, pardo } \\
\text { fluorescente }\end{array}$ \\
\hline $\mathbf{M n}^{3+}$ & Púrpura & - \\
\hline $\mathbf{M n}^{2+}$ & Incolor & $\begin{array}{c}\text { Laranja suave, } \\
\text { Vermelho fluorescente }\end{array}$ \\
\hline $\mathbf{F e}^{3+}$ & Amarelo claro, Verde & incolor \\
\hline $\mathbf{F e}^{2+}$ & - & Verde escuro \\
\hline $\mathbf{N i}^{2+}$ & Púrpura & Amarelo \\
\hline
\end{tabular}

Fonte: SALMANG, H.; SÁNCHEZ-CONDE, M. C.; ALEIXANDRE, V. Fundamentos físico-químicos de la fabricación del vidrio. 1ํㅡㄹ. Madrid Aguilar: 1962.[32]

\subsection{Durabilidade Química}

O vidro, quando em contato com o ambiente, sofre reações que podem modificar sua composição e, consequentemente, alterar suas propriedades. Por este motivo, é de extrema relevância acompanhar tais reações para prever o comportamento do material e principalmente para determinar sua vida útil [33].

Um dos parâmetros mais acompanhados, principalmente no setor de embalagem, é a durabilidade química. Quando um vidro entra em contato com um meio aquoso, 
pode sofrer corrosão, causando alterações tanto na sua composição química, quanto no $\mathrm{pH}$ do meio em questão.

A avaliação desta corrosão é associada ao estudo da durabilidade química através de ensaios de resistência hidrolítica, sob os quais amostras de tamanho específico são expostas à um meio aquoso para remoção dos constituintes solúveis presentes [34].

Para quantificar tal avaliação, existe a razão de dissolução (RD), a qual indica a perda de massa do material em função do tempo e da área superficial da amostra.

A razão de dissolução é dada através da seguinte equação:

$$
R D(t)=\frac{m_{f}-m_{i}}{S_{0} t}
$$

Onde $m_{i}$ é a massa inicial da amostra em gramas, $m_{f}$ é a massa final da amostra em gramas, So é a área superficial em $\mathrm{cm}^{2}$ e t, o tempo do ensaio em dias [35].

O ensaio é realizado em acordo com a norma técnica ISO 695-1984 (E), que exige um controle de volume da solução a qual as amostras são expostas, além da possibilidade do controle do $\mathrm{pH}$ durante todo o período. O procedimento imposto pela norma é descrito na sessão de procedimento experimental [36]. 


\section{MATERIAIS E MÉTODOS}

\subsection{Matérias-primas}

Os materiais utilizados para o presente estudo foram: a cinza da casca de arroz, denominado como "CCA", o resíduo de catalizador exaurido das petroquímicas, denominado "ECAT", carbonato de sódio comercial $\left(\mathrm{Na}_{2} \mathrm{CO}_{3}\right.$, 95\%) e óxido de cálcio ( $\mathrm{CaO}, 99 \%)$.

\subsection{Resíduos}

O resíduo CCA utilizado neste trabalho foi concedido pela empresa TECSOL (São Paulo) que utiliza a casca do arroz como fonte de energia elétrica para suas instalações. E o resíduo ECAT é resultante dos processos da refinaria RECAP (Capuava - SP);

\subsection{Embalagens}

As embalagens utilizadas como referência neste trabalho, com fins comparativos, foram da empresa Natura da linha de perfumes "Águas Campo de Violetas" (Vidro 1 e 2) e da linha Lily do grupo O Boticário (Vidro 3 e 4), todos do fabricante Nadir Figueiredo.

\subsection{Técnicas de análise}

As matérias-primas e as amostras obtidas foram caracterizadas utilizando as técnicas apresentadas a seguir. 


\subsubsection{Espectrometria por Fluorescência de Raios- X (FRX)}

O espectrômetro de fluorescência de raios $X$ é um instrumento que determina quantitativamente (percentuais em massa) os elementos presentes em uma determinada amostra. Isto é possível através da aplicação de raios $X$ na superfície da amostra e a posterior análise dos fluorescentes raios X emitidos. Quando o feixe de raios $\mathrm{X}$ incide sobre um material, os elétrons fortemente ligados (camada $\mathrm{K}$ ) dos átomos e dos íons constituintes são excitados, mudando de níveis energéticos. Ao retornarem para sua posição inicial, liberam a energia adquirida a qual é emitida em comprimento de onda no espectro de raios $\mathrm{X}$. Como os elétrons de um determinado átomo possuem energias distintas, é possível, no ponto de incidência do feixe, determinar quais os elementos químicos estão presentes naquele local e assim identificar que material está sendo observado [38].

A técnica de fluorescência de raios $X$ não é destrutiva. Elementos de alto peso molecular, que possuem mais subníveis de energia, são mais fáceis de serem detectados por este método. Os raios $\mathrm{X}$ produzidos são coletados por um detector, e interpretados por conversão da energia radiativa em sinais elétricos. O gráfico gerado é uma sucessão de picos correspondentes a cada elemento químico, embora a altura desses picos não corresponda, necessariamente, a sua proporção em massa [38]. As porcentagens de massa de cada material são calculadas segundo modelos previamente programados e fornecidos ao software.

As amostras foram submetidas à análise em um Espectrômetro de Fluorescência de raios $X$ por Energia Dispersiva, modelo EDX-720, da Shimadzu. A medida foi realizada em vácuo, abrangendo uma área da amostra de $10 \mathrm{~mm}^{2}$ com tempo de leitura de aproximadamente 30 segundos e colimador de $3 \mathrm{~mm}$. As medidas foram realizadas no Centro de Ciência e Tecnologia de Materiais (CCTM-IPEN). 


\subsubsection{Espectrometria por Difração de Raios-X (DRX)}

Esta técnica é realizada para determinar parâmetros cristalográficos e a estrutura cristalina. A radiação incide sobre a superfície formando um ângulo $(\theta)$ com a normal. A intensidade da radiação difratada é medida também a um ângulo $(\theta)$ em relação à normal da amostra, ou seja, um ângulo $2 \theta$ em relação ao feixe incidente. $O$ resultado da varredura fica registrado na forma de um diagrama de intensidade versus ângulo de varredura [39].

O método de análise consiste na exposição do material a um feixe de raios monocromáticos incidente sobre a amostra, posicionada num ângulo $\theta$ variado continuamente.

Pode-se avaliar a cristalinidade do material pelos picos encontrados. Caso não haja picos significativos, o material pode ser considerado amorfo [40].

A difração de raios $X$ foi realizada no Laboratório de Difração de Raios-X do Centro de Ciência e Tecnologia de Materiais (CCTM-IPEN). O equipamento utilizado foi um difratômetro Rigaku Miniflex, aplicando uma radiação característica de $\mathrm{Cu} \mathrm{k}_{\alpha}$ com tensão de $30 \mathrm{kV}$ e corrente de $15 \mathrm{~mA}$. Foi utilizado ângulo de varredura $2 \theta$ entre 2 e $100^{\circ}$. O passo utilizado foi de $0,05^{\circ}$ e o tempo de contagem de $1 \mathrm{~s}$.

A análise dos dados foi feita no programa X'Pert HighScore, versão 2.1. As fichas de difração são provenientes da JCPDS - International Centre for Diffraction Data.

\subsubsection{Diâmetro médio equivalente (distribuição granulométrica por dispersão a laser)}

A técnica de dispersão a laser proporciona o conhecimento do tamanho médio de grãos e a distribuição do tamanho de partícula a partir de um histograma 
representando a porcentagem em peso que cada fração possui em relação à massa total da amostra [38].

O método de espalhamento de luz, também chamado de Difração Fraunhofer, consiste em atingir as partículas em um meio fluido com um laser que possua um comprimento de onda menor do que o diâmetro das partículas em questão. Quando o feixe de luz (laser) atinge uma quantidade de partículas, parte desta luz é espalhada, parte é absorvida e outra transmitida [38].

Através de lentes, fotodetectores e um microprocessador, a luz espalhada será captada e transformada em energia para distribuição volumétrica das partículas, considerando que tais partículas possuem formato esférico. O princípio do método é que o ângulo de difração é inversamente proporcional ao tamanho de partícula [25].

Ambos os resíduos foram submetidas a análise de difração a laser utilizando como agente dispersante o pirofosfato de sódio e como fluido a água. Esta análise foi realizada em um granulômetro a laser do Centro de Ciência e Tecnologia de Materiais (CCTM-IPEN).

\subsubsection{Análise morfológica por Microscopia Eletrônica de Varredura (MEV)}

O microscópio eletrônico de varredura (MEV) é um equipamento capaz de produzir imagens de alta resolução, da ordem de $100 \AA$. E é utilizado par examinar e analisar características microestruturais de objetos sólidos [40].

As imagens fornecidas pelo MEV possuem um caráter virtual, pois o que é visualizado no monitor do aparelho é a trans-codificação da energia emitida pelos elétrons, ao contrário da radiação de luz visível à qual estamos habitualmente acostumados[41].

As obtenções das imagens topográficas da amostra são realizadas através da utilização de elétrons de baixa energia, da ordem de $50 \mathrm{eV}$. Já as informações sobre 
número atômico ou orientação dos átomos, são obtidas a partir da utilização de elétrons de alta energia[40].

O princípio de funcionamento do MEV consiste na emissão de feixes de elétrons por um filamento capilar de tungstênio (eletrodo negativo), mediante a aplicação de uma diferença de potencial que pode variar de 0,5 a $30 \mathrm{KV}$. Essa variação de diferença de potencial permite a variação da aceleração dos elétrons e também provoca o aquecimento do filamento. A parte positiva em relação ao filamento do microscópio (eletrodo positivo) atrai fortemente os elétrons gerados, resultando numa aceleração em direção ao eletrodo positivo. A correção do percurso dos feixes é realizada pelas lentes condensadoras que alinham os feixes em direção à abertura da objetiva. A objetiva ajusta o foco dos feixes de elétrons antes dos elétrons atingirem a amostra analisada [[40]-[41]].

A Figura 4, representa o esquema de formação de imagem em um microscópio eletrônico de varredura.

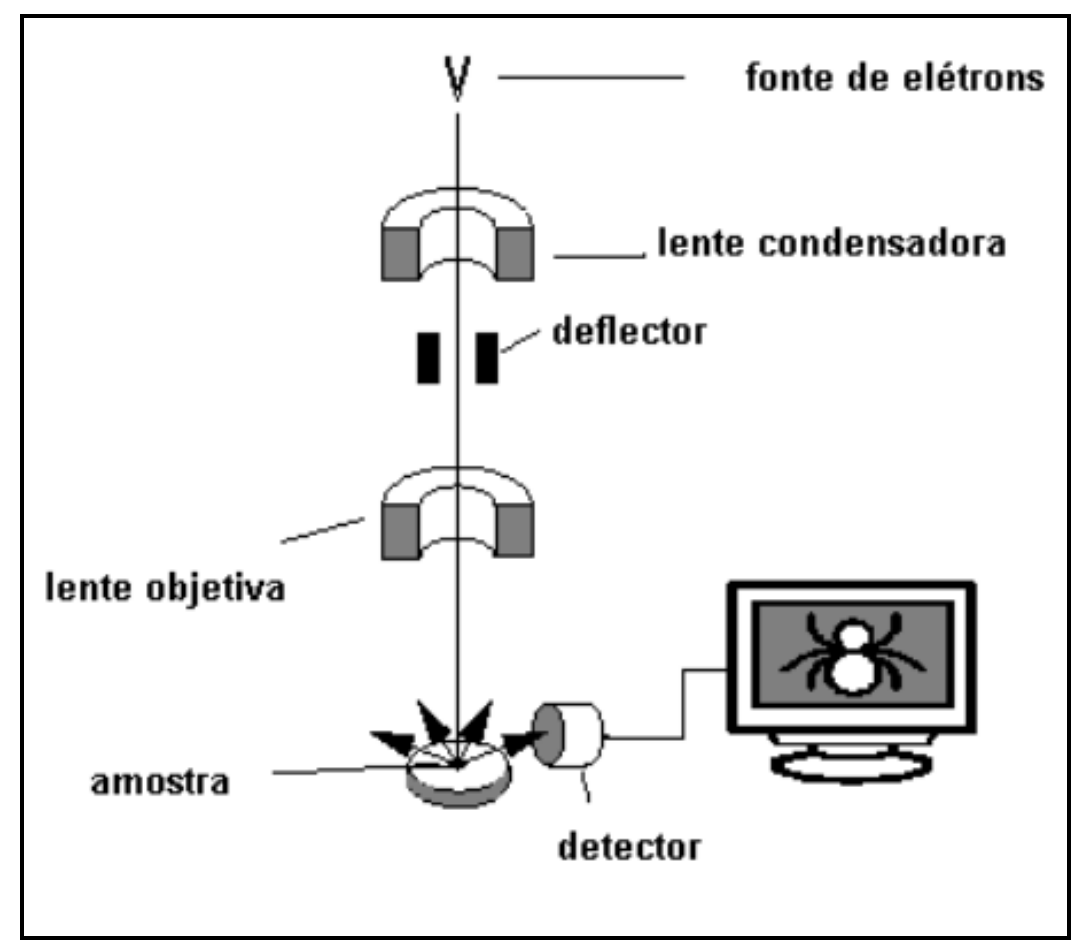

Figura 4. Representação esquemática dos componentes de um microscópia eletrônico de varredura. Fonte: Adaptado pelo autor [40]. 
Já a Figura 5, representa a interação que ocorre entre o elétron e a amostra durante a realização da análise e incidência do feixe de elétrons.

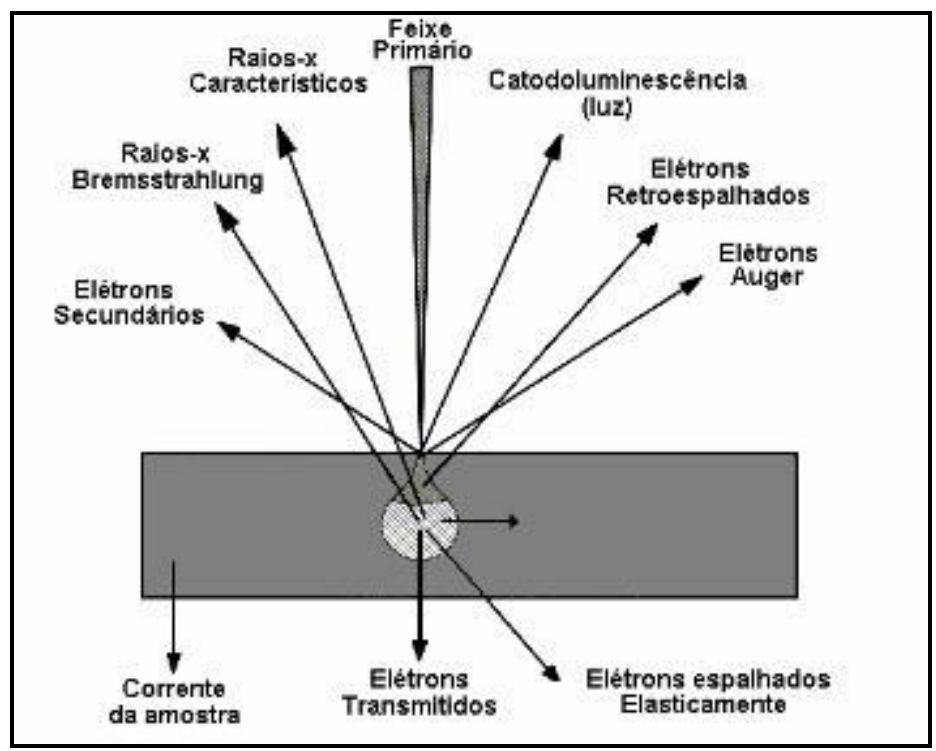

Figura 5. Interação elétron-amostra durante a análise por microscopia eletrônica de varredura. Fonte: Adaptado pelo autor [40].

Deve-se ressaltar que a resolução de um MEV está diretamente relacionada com a dimensão da zona excitada pelo feixe primário sobre a amostra. E tal interação resulta em diversos processos de interação com os átomos próximos, conforme visualizado na Figura 5.

Para a realização das análises, a amostra deve ser condutora eletricamente, caso contrário, deve-se realizar uma preparação da superfície através de um recobrimento metálico (normalmente ouro) ou de carbono através da deposição, para monólitos, ou, a impregnação em fita de carbono, para pós (normalmente cerâmicos) [40]. 
As análises de MEV foram feitas no equipamento Nova NanoSEM da Fei Company no Laboratório de Sistemas Integráveis (LSI) da Escola Politécnica da Universidade de São Paulo (EPUSP). Foi utilizada uma fita de carbono para realizar o contato elétrico dos pós analisados.

\subsubsection{Análise de defeitos volumétricos e homogeneização por Microscopia Óptica (MO)}

Apesar das técnicas mais sofisticadas disponíveis atualmente, a microscopia óptica é ainda uma das mais utilizadas na observação, análise e documentação de materiais.

Neste trabalho o microscópio ótico foi utilizado com o objetivo de identificar e analisar a presença de defeitos volumétricos e a homogeneidade das amostras vítreas produzidas, uma vez que permite observar imagens com resolução máxima de 250nm [40].

A utilização deste recurso para análise de superfície de materiais vem sido mencionada desde 1863, quando Sorby observou pela primeira vez uma estrutura metálica ao microscópio [41].

Em um microscópio óptico, um feixe de luz passa por uma série de lentes e espelhos atingindo então a amostra. O feixe é refletido pela superfície da amostra passando novamente pelas lentes até atingir a lente ocular por onde é possível observar a estrutura ampliada [40].

A Figura 6, representa o esquema de formação de imagem em um microscópio óptico. 


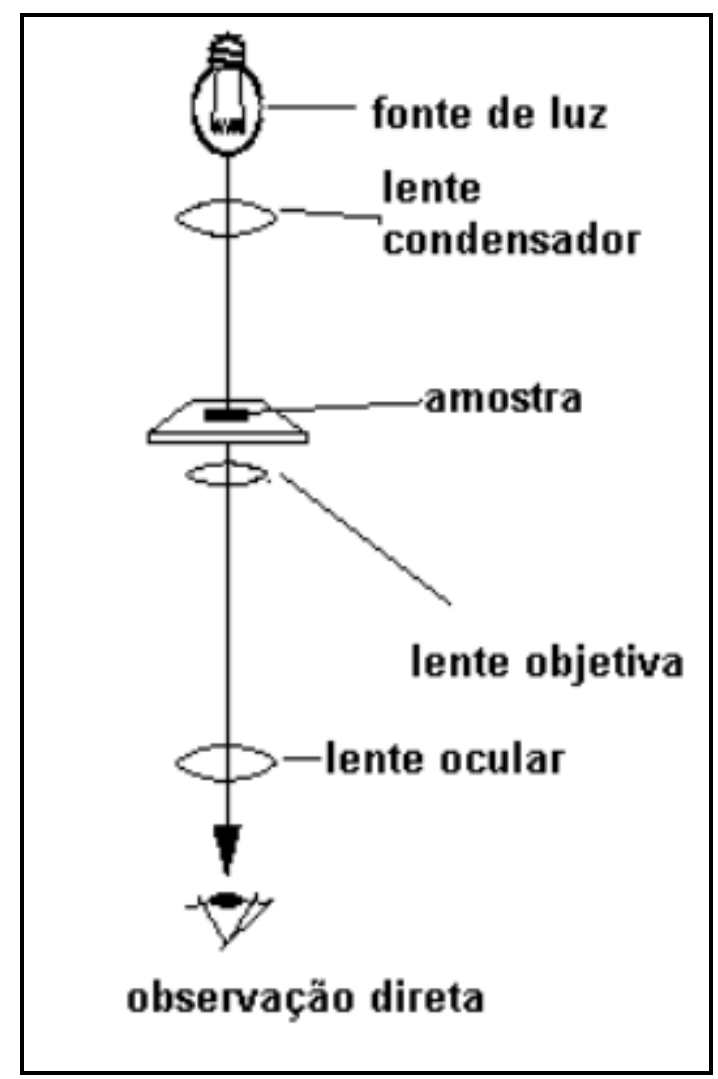

Figura 6. Diagrama esquemático de um microscópio óptico. Fonte: Adaptada pelo autor [40].

Para a observação, é possível basicamente três tipos de iluminações. Entre elas, a iluminação vertical (campo claro), oblíqua e de alto ângulo (campo escuro). Neste trabalho, foi utilizada apenas a iluminação vertical, ou seja, de campo claro.

$\mathrm{Na}$ iluminação de campo claro o feixe de luz incide perpendicularmente sobre a superfície do corpo de prova. De forma que, as pequenas variações da superfície do corpo irão gerar o contraste luz-sombra fazendo com que a luz refletida ao chegar à lente ocular, forme a imagem observada.

Em geral, a técnica de campo claro, é suficiente para a observação da estrutura da superfície da amostra. Apenas materiais sólidos podem ser examinados utilizando técnicas de reflexão, principalmente por limitar o campo de profundidade. 
As amostras vítreas obtidas foram submetidas à análise por microscopia óptica utilizando o equipamento microscópio óptico da marca CARL ZEISS, do Centro de Ciência e Tecnologia de Materiais (CCTM-IPEN).

\subsubsection{Análise Térmica Diferencial (ATD)}

A análise térmica pode ser definida como a medida de propriedades físicas e químicas de materiais em função da temperatura. Entretanto, as análises térmicas realizadas atualmente são utilizadas para determinar algumas propriedades específicas, entre elas: entalpia, coeficiente de expansão térmica, temperatura de fusão e etc [42].

A análise térmica diferencial (ATD) é uma técnica experimental utilizada na área de materiais em geral e extremamente útil para o estudo de materiais vítreos. Através dela é possível identificar transformações físicas e químicas, ou qualquer transição que envolva troca de calor [42].

A técnica em si trata-se de uma medição contínua que permite a comparação da temperatura entre a amostra a ser estudada e uma de referência inerte termicamente. Desta forma, a diferença entre essas temperaturas, é na verdade uma função que dá origem a uma curva. E por ser uma técnica com elevada sensibilidade, as trocas de calor resultam em variações na linha de base desta curva indicando picos exotérmicos (liberação de calor) ou endotérmicos (absorção de calor) [42].

A partir desta análise, pode-se determinar as temperaturas de trabalho do material, como sua temperatura de fusão e de transição vítrea [42].

A análise foi realizada em um equipamento da marca Netzsch, modelo Pegasus 404 com ar sintético dinâmico com velocidade de aquecimento de $10^{\circ} \mathrm{C} / \mathrm{min}$ em cadinhos de alumina e temperaturas entre $25^{\circ}$ e $1300^{\circ} \mathrm{C}$, no Centro de Ciência e Tecnologia de Materiais (CCTM-IPEN). 


\subsubsection{Espectrometria de Transmitância e Absorbância no UV-VIS}

A espectrometria de luz ultravioleta (UV) e visível (VIS) é utilizada para obter o espectro de transmitância das amostras vítreas. Esta técnica consiste na incidência de um feixe de luz de comprimento de onda conhecido ortogonalmente sobre a amostra, tomando a transmitância ou absorbância para cada comprimento de onda. Desta forma, pode-se obter um gráfico da variação da transmitância ou absorbância em função do comprimento de onda [38].

A transmitância foi medida no espectrofotômetro Ocean. Optes, com varredura variando entre $350 \mathrm{~nm}$ e $1000 \mathrm{~nm}$. Esta análise foi realizada no laboratório LTMFO da FATEC-SP.

\subsubsection{Medidas de cor no sistema CIE}

O sistema mais conhecido utilizado para classificação de cor de materiais no meio científico foi desenvolvido pela Comissão Internacional de lluminação (CIE) [43].

A CIE é uma comissão técnica, científica e cultural, aceita como a melhor representante mundial sobre iluminação e cor. Esta comissão padronizou matematicamente as cores, apresentando-as em coordenadas (XYZ) através de gráficos (diagrama CIE).

O sistema $\mathrm{XYZ}$ de cores primárias da CIE descreve as cores através de três cores primárias virtuais: $X, Y$ e $Z$. Desta forma, qualquer cor pode ser definida apenas pelas coordenadas de cromaticidade, denominadas $\mathrm{x}$ e $\mathrm{y}$.

A Figura 7, representa o diagrama CIE desenvolvido, de forma que os pontos internos correspondem a todas as combinações possíveis de cores visíveis, e o ponto central corresponde à posição da luz branca. 


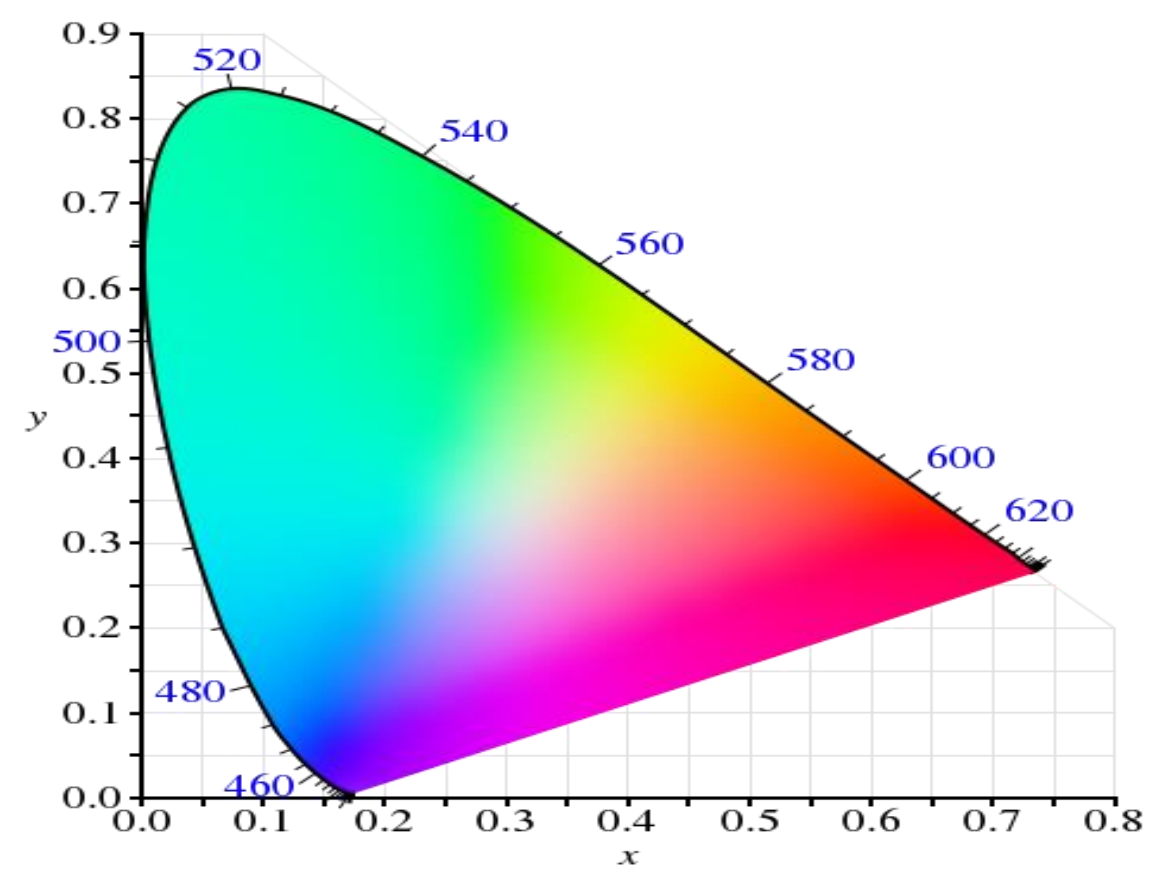

Figura 7. Diagrama CIE de coordenadas colorimétricas [43]

Por meio deste diagrama, é possível determinar e comparar os espaços de cores dos diferentes conjuntos de cores primárias, identificar as cores complementares, determinar o comprimento de onda dominante e a saturação de uma cor.

As medidas foram realizadas no espectrofotômetro Ocean Optics, utilizando o iluminante D65 (luz do dia). Esta análise foi realizada no laboratório LTMFO da FATEC-SP. 


\subsubsection{Ensaio de Lixiviação}

\subsubsection{Ensaio dinâmico}

Os ensaios de lixiviação foram realizados de acordo com a segunda edição da norma técnica ISO 695-1984 (E), a $90^{\circ} \mathrm{C}$ em soluções de água destilada, por 14 dias, para determinar a durabilidade química dos vidros [37].

A sequência para este ensaio é apresentada a seguir:

1. Corte das amostras com dimensões de $1 \times 10 \times 10 \mathrm{~mm}^{3}$;

2. Lixamento das faces em água, utilizando-se lixa de SiC, com grano de 100, 120,180 e 240 mesh;

3. Lavagem com acetona em ultrassom por 10 minutos;

4. Secagem em estufa a $110^{\circ} \mathrm{C}$ durante $2 \mathrm{~h}$ e resfriamento em um dessecador;

5. Pesagem da amostra em uma balança com precisão de 0,00001 MG;

6. Uso de vidraria analítica do tipo Soxlet contendo $250 \mathrm{~mL}$ de água destilada a $90^{\circ} \mathrm{C}$ para imersão da amostra;

7. Pesagem das amostras após 1, 3, 7,14 dias do início de imersão.

As amostras vítreas obtidas foram submetidas ao ensaio e este foi realizado em triplicata, ou seja, de cada amostra obtida foi retirada três sub-amostras para cada ensaio, a fim de agregar maior confiabilidade aos resultados. 


\subsubsection{Ensaio estático}

$\mathrm{Na}$ impossibilidade da realização do ensaio em vidraria Soxlet, com resfriamento contínuo da aparelhagem durante todo o ensaio, pode-se realizar sua versão estática, isto é, em estufa pré-aquecida a $90^{\circ} \mathrm{C}$ e frascos em polietileno Nalgon.

Os ensaios estáticos de lixiviação foram realizados de acordo com a segunda edição da norma técnica $695-1984$ (E), a $90^{\circ} \mathrm{C}$ em soluções de água destilada, por 14 dias, para determinar a durabilidade química dos vidros [37].

A sequência para este ensaio é apresentada a seguir:

Corte das amostras com dimensões de $1 \times 10 \times 10 \mathrm{~mm}^{3}$;

1. Lixamento das faces em água, utilizando-se lixa de SiC, com grano de 100, 120,180 e 240 mesh;

2. Lavagem com acetona em ultrassom por 10 minutos;

3. Secagem em estufa a $110^{\circ} \mathrm{C}$ durante $2 \mathrm{~h}$ e resfriamento em um dessecador;

4. Pesagem da amostra em uma balança com precisão de $0,00001 \mathrm{mg}$;

5. Uso de um recipiente de PE (Nalgon) contendo $100 \mathrm{~mL}$ de água destilada a $90^{\circ} \mathrm{C}$ para imersão da amostra;

6. Estufa pré-aquecida a $90^{\circ} \mathrm{C}$ para acondicionar os recipientes e manter a temperatura de $90^{\circ} \mathrm{C}$ por todo o período do ensaio.

7. Pesagem das amostras após 1, 3, 7,14 dias do início de imersão.

As amostras vítreas obtidas foram submetidas ao ensaio e este foi realizado em triplicata, ou seja, de cada amostra obtida foi retirada três sub-amostras para cada ensaio, a fim de agregar maior confiabilidade aos resultados. 


\subsection{Procedimento Experimental}

A Figura 8, ilustra o esquema adotado para condução do procedimento experimental.

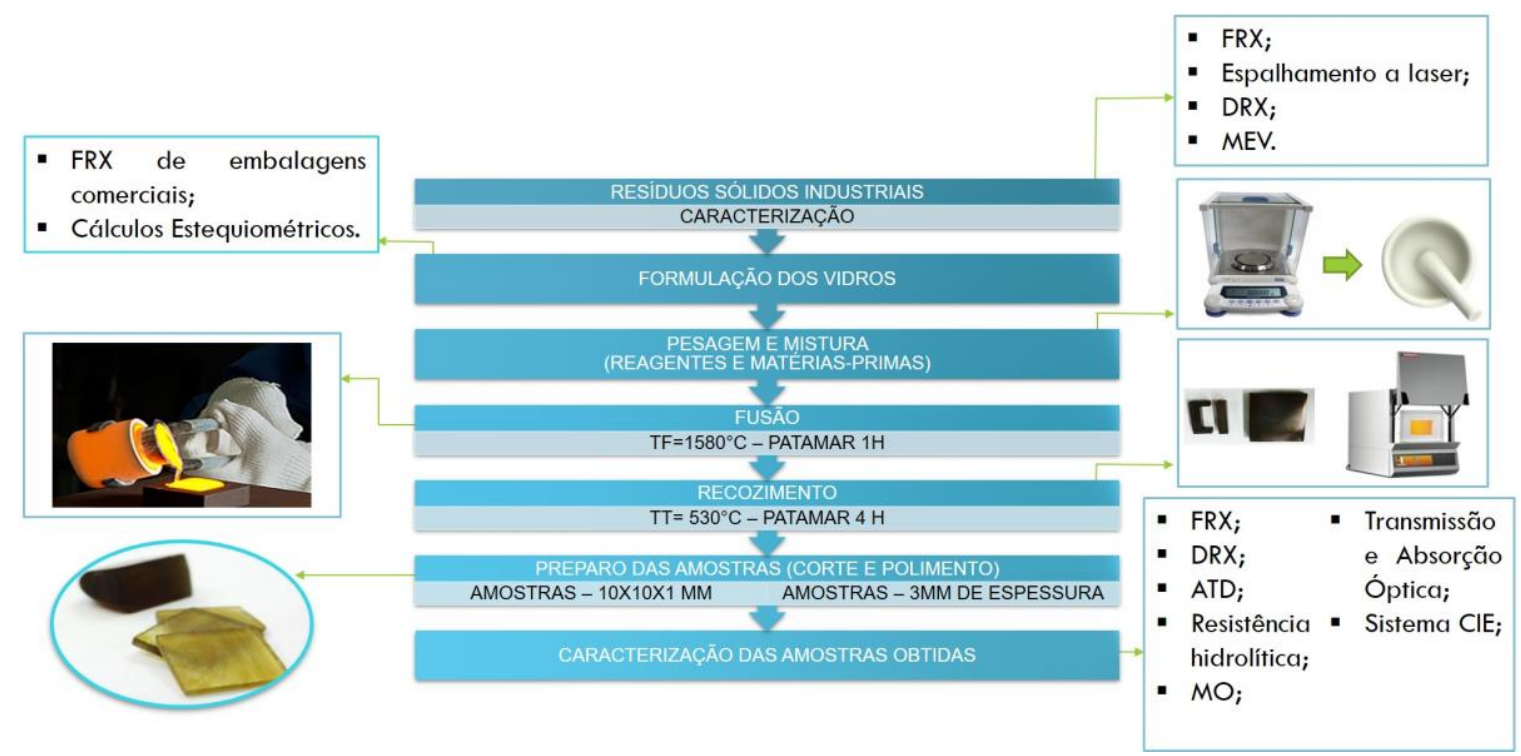

Figura 8. Esquema ilustrativo do procedimento experimental adotado.

Onde, FRX corresponde à técnica de fluorescência de Raios-X, DRX à difração de Raios-X, MEV à microscopia eletrônica de varredura, ATD à análise térmica diferencial e MO à microscopia óptica.

\subsubsection{Formulação dos vidros}

Neste trabalho, foi tomado como base um intervalo de composições comumente utilizado na produção de vidros embalagens empregados na indústria. A composição dos vidros produzidos foi estabelecida através de cálculos estequiométricos concomitantes a análise da composição química por fluorescência de raios- $X$ de amostras utilizadas no mercado de embalagens [[26];[44]].

Foi realizada uma aproximação de composição baseando-se na composição química dos resíduos, de maneira que os teores de sílica e alumina indicados tiveram como fonte integral os resíduos como recebido, ou seja, sem qualquer 
beneficiamento prévio, proporcionando também à composição os teores dos óxidos minoritários.

\subsubsection{Pesagem e Mistura}

As matérias-primas foram devidamente separadas e pesadas em balança analítica. Sua mistura foi realizada manualmente em um almofariz de porcelana e após, a mistura obtida foi transferida para os cadinhos de alta alumina.

\subsubsection{Fusão}

A fusão da mistura obtida foi realizada em forno elétrico (marca Lindberg modelo Blue $\mathrm{M}$ ) a $1580^{\circ} \mathrm{C}$ com taxa de aquecimento de $10^{\circ} \mathrm{C} / \mathrm{min}$ e patamar de uma hora. $\mathrm{A}$ massa fundida foi vertida em molde de aço inoxidável pré-aquecido a $530^{\circ} \mathrm{C}$.

\subsubsection{Recozimento}

O recozimento (recozimento) foi realizado em forno elétrico tipo mufla (marca Quimis) a $530^{\circ} \mathrm{C}$ com taxa aquecimento de $10^{\circ} \mathrm{C} / \mathrm{min}$ e patamar de quatro horas.

O recozimento é realizado para melhorar a estabilidade do vidro pelo alívio das tensões térmicas geradas, como decorrência da alta velocidade de resfriamento, que pode gerar defeitos no vidro, como o aparecimento de trincas e fraturas. Em adição, a fim de evitar possíveis tensões, o resfriamento após o tratamento deve ser realizado lentamente dentro do forno até chegar à temperatura ambiente.

\subsubsection{Corte e preparo das amostras}

As amostras obtidas foram cortadas em lâminas finas de $1 \mathrm{~mm}$ e $3 \mathrm{~mm}$ utilizando uma cortadora (marca ISOMET, modelo 2000), e um disco com superfície impregnada com diamante. 


\section{RESULTADOS E DISCUSSÃO}

\subsection{Caracterização das matérias-primas}

Os resultados da caracterização dos resíduos utilizados neste trabalho são apresentados a seguir.

\subsubsection{Cinza da Casca de Arroz (CCA)}

A Figura 9 apresenta uma macrografia ilustrando o aspecto da CCA como recebido, sem qualquer beneficiamento. Trata-se de um pó fino de coloração cinza escuro.

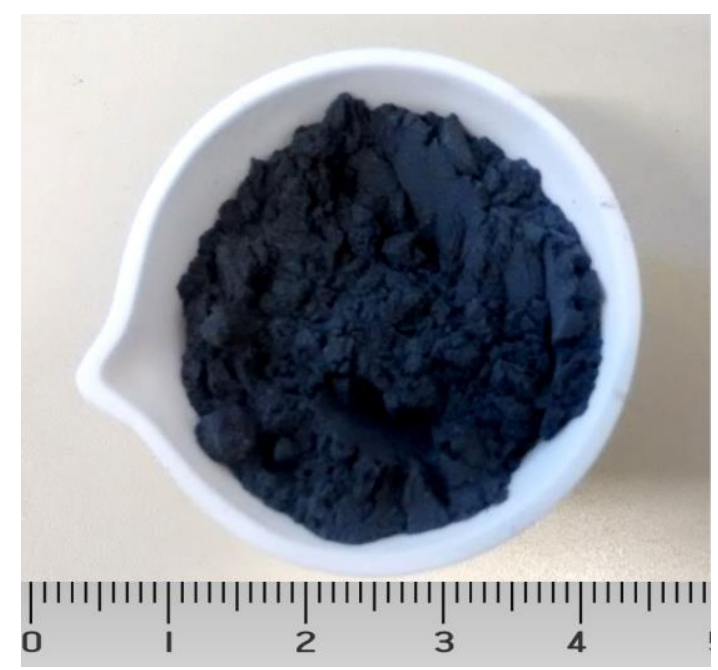

Figura 9. Macrografia do resíduo cinza da casca de arroz (CCA).

Foi realizada análise por microscopia eletrônica de varredura de uma amostra do montante recebido. E, de acordo com as micrografias obtidas da CCA, apresentadas na Figura 10, a morfologia das partículas mostrou-se irregular, sendo que, é nítida a presença de extremidades angulosas e pontiagudas. A rugosidade observada na partícula destacada da Figura 10 (a), provém do formato natural da casca de arroz [45]. 

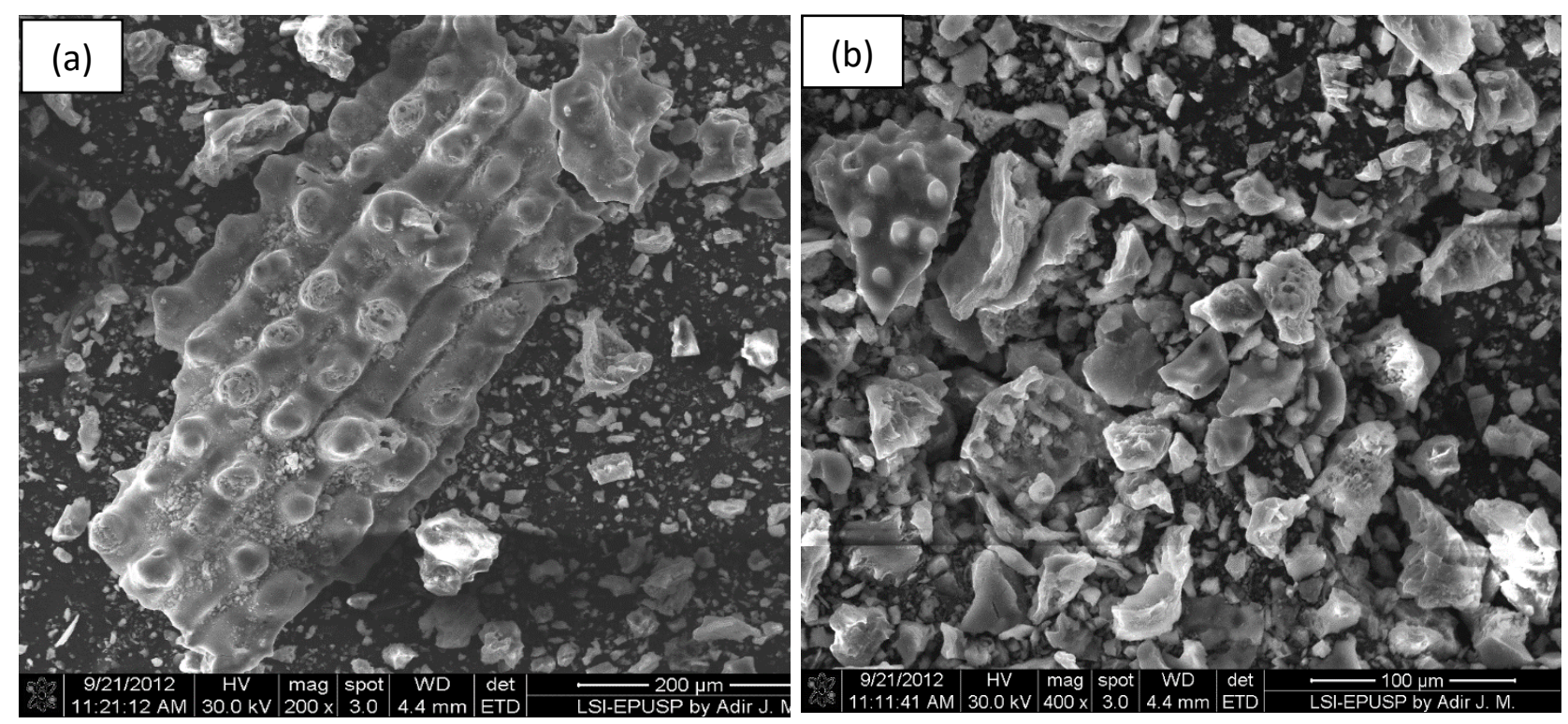

Figura 10. (a) e (b) Micrografias da cinza da casca de arroz (CCA) obtidas por microscopia eletrônica de varredura.

A análise granulométrica da CCA apresentou a variação no diâmetro das partículas com resultados entre 1,0 e $100 \mu \mathrm{m}$ e diâmetro médio de aproximadamente $32 \mu \mathrm{m}$. Este valor de granulometria média está de acordo o tamanho de partícula observado nas micrografias da CCA apresentadas anteriormente.

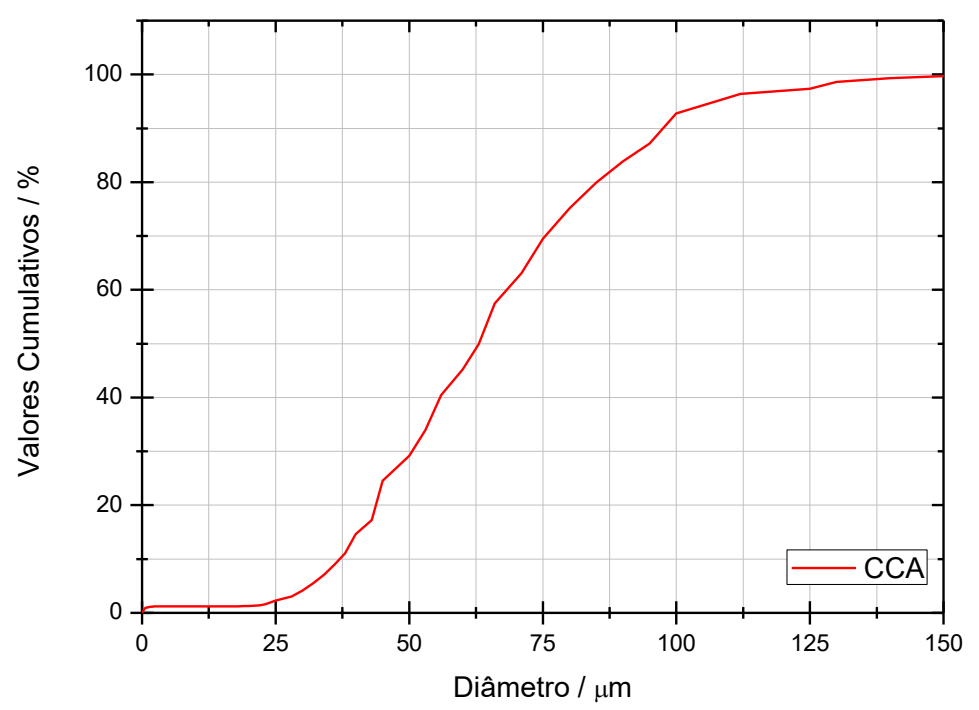

Figura 11. Distribuição granulométrica da cinza da casca de arroz (CCA) obtida por espalhamento a laser. 
Abaixo se podem observar as composições químicas encontradas em porcentagem em peso nos resíduos utilizados. Na Tabela 5, podemos observar a composição da CCA.

Tabela 5. Composição química em porcentagem em massa do resíduo CCA obtida pela técnica de fluorescência de raios-X.

\begin{tabular}{|c|c|c|c|c|c|c|c|c|}
\hline $\begin{array}{c}\% \text { em } \\
\text { massa }\end{array}$ & $\mathrm{SiO}_{2}$ & $\mathrm{~K}_{2} \mathbf{O}$ & $\mathbf{C a O}$ & $\mathbf{P}_{2} \mathrm{O}_{5}$ & $\mathrm{MnO}$ & $\mathrm{Fe}_{2} \mathrm{O}_{3}$ & Outros & PF \\
\hline CCA & 87,4 & 1,9 & 0,7 & 0,4 & 0,2 & 0,1 & $<0,1$ & 9,3 \\
\hline
\end{tabular}

Analisando o difratograma da CCA da Figura 12, observa-se que a sílica encontrada está na forma de cristobalita (picos correspondem a presença de uma das fases cristalinas polimórficas da sílica). Este resultado já era esperado, uma vez que a queima da casca de arroz ocorre em temperaturas favoráveis para a formação desta fase da sílica [[45]-[47]]

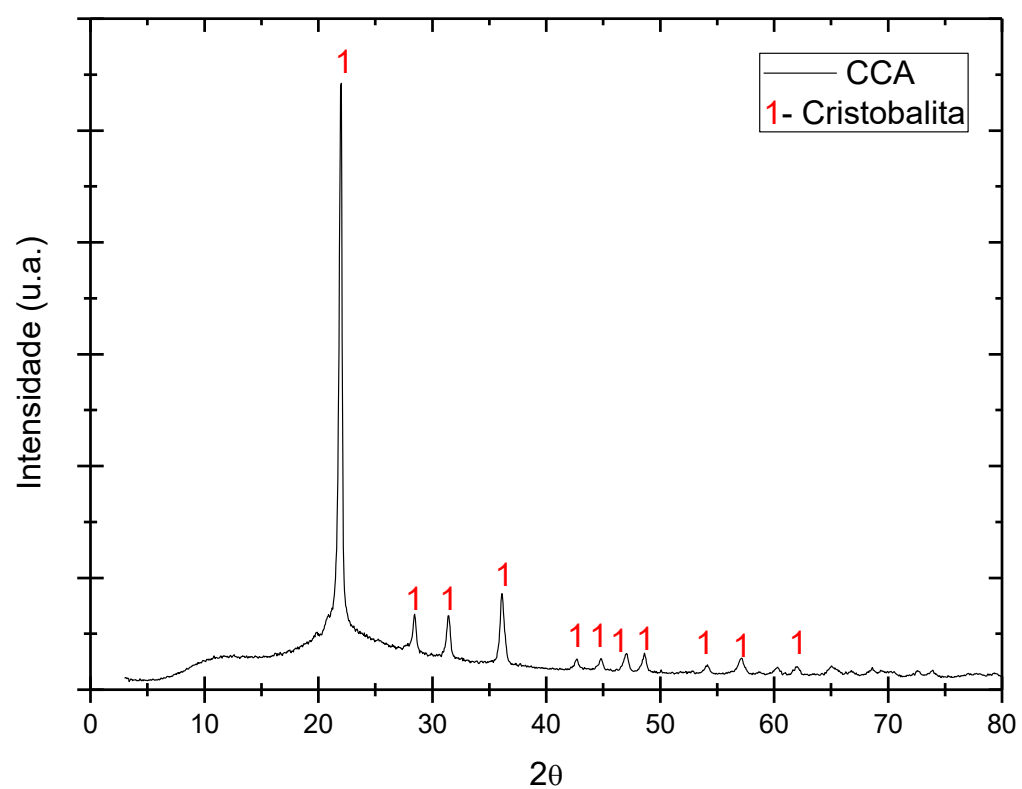

Figura 12. Análise obtida por difração de raios- $X$ da cinza da casca de arroz (CCA). 


\subsubsection{Resíduo de catalisador exaurido (ECAT)}

A Figura 13, apresenta uma macrografia ilustrando o aspecto do resíduo de catalisador exaurido (ECAT) como recebido. Trata-se de um pó fino de coloração amarelo esverdeada.

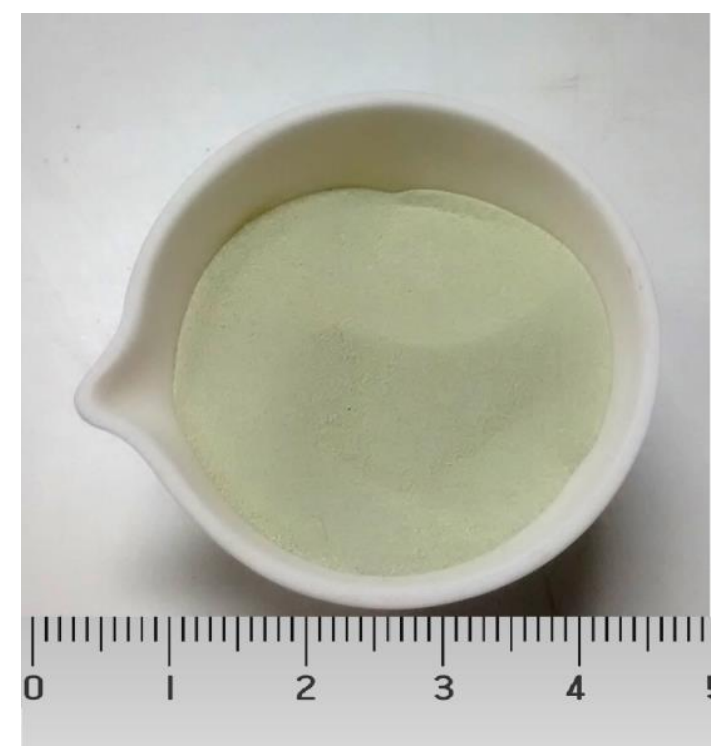

Figura 13. Macrografia do resíduo de catalizador exaurido (ECAT).

Foi realizada análise por microscopia eletrônica de varredura de uma amostra do montante recebido. As micrografias obtidas, apresentadas na Figura 14, revelaram que o ECAT possui partículas com morfologia regular e de formato arredondado, característico deste tipo de resíduo [48]. 

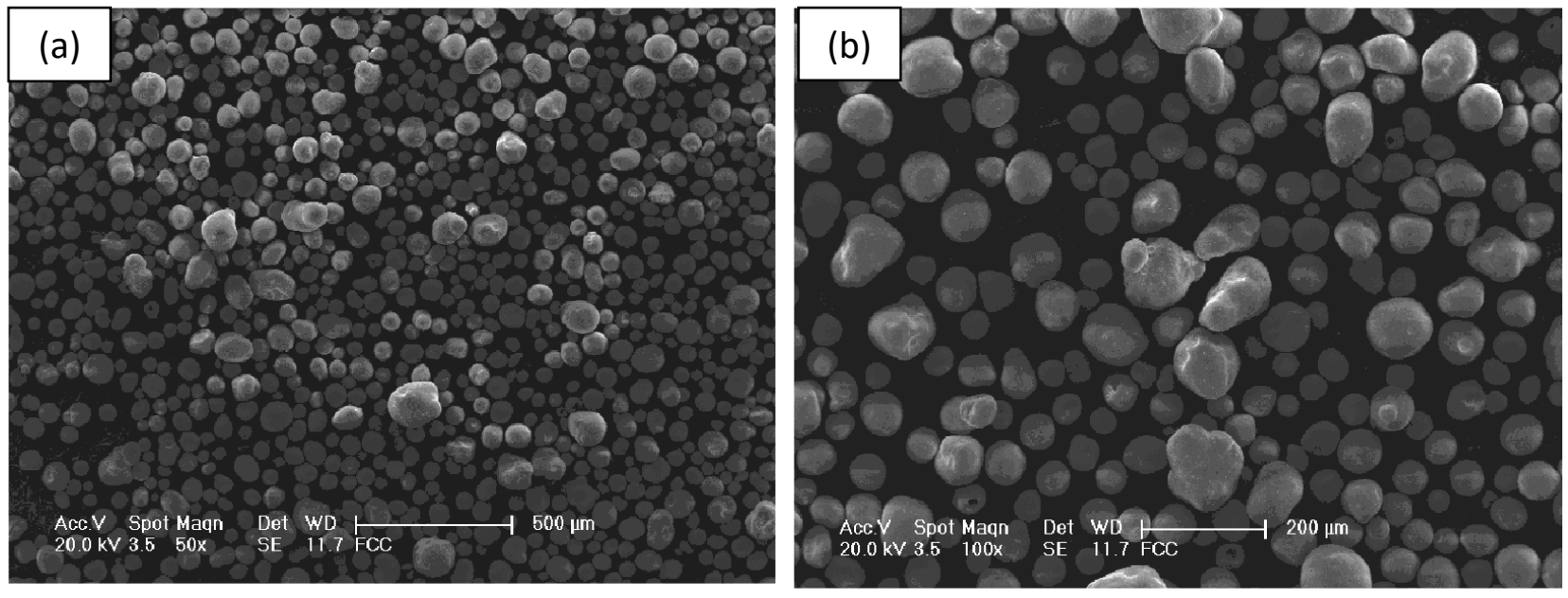

Figura 14. (a) e (b) Micrografias do resíduo de catalizador exaurido (ECAT) obtidas por microscopia eletrônica de varredura (MEV).

Já na Tabela 6, podemos observar a composição química em \% em peso do resíduo ECAT.

Tabela 6. Composição química em porcentagem em massa do resíduo de catalizador exaurido (ECAT) obtida por fluorescência de raios-X.

\begin{tabular}{|c|c|c|c|c|c|c|c|c|}
\hline \% em massa & $\mathbf{S i O}_{2}$ & $\mathbf{A l}_{2} \mathbf{O}_{3}$ & $\mathbf{L a}_{2} \mathbf{O}_{3}$ & $\mathbf{V}_{\mathbf{2}} \mathbf{O}_{\mathbf{5}}$ & $\mathbf{N i O}$ & $\mathbf{F e}_{2} \mathbf{O}_{3}$ & Outros & PF \\
\hline ECAT & 44,4 & 49,4 & 2,8 & 1,2 & 0,8 & 0,8 & 0,6 & 4,9 \\
\hline
\end{tabular}

A partir da análise granulométrica realizada, o ECAT apresentou uma variação no

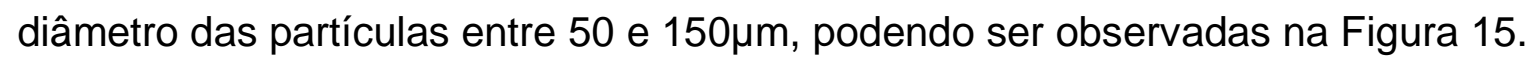




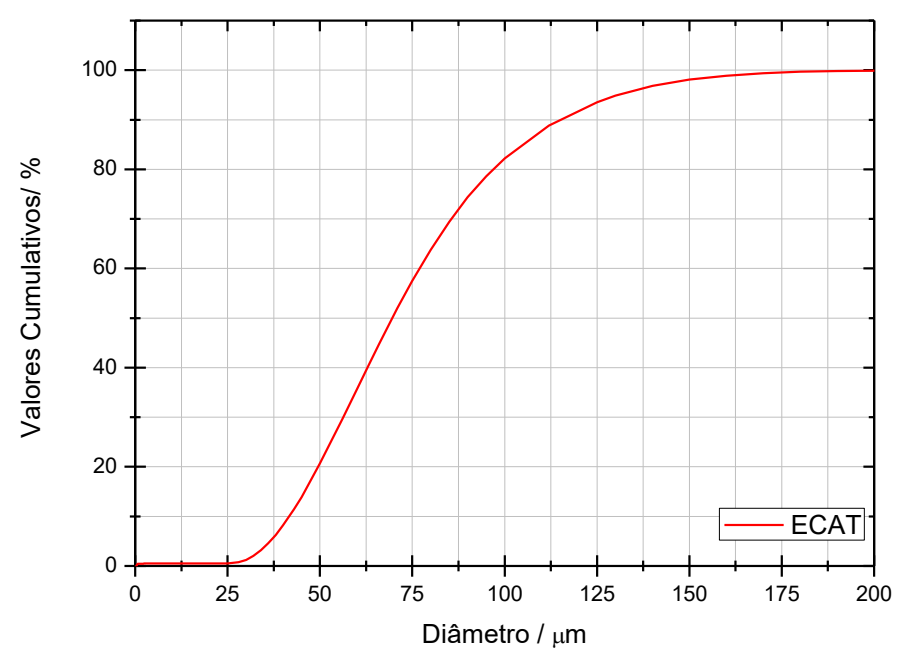

Figura 15. Distribuição granulométrica do resíduo de catalizador exaurido (ECAT) obtida por espalhamento a laser.

A partir da análise obtida por DRX, Figura 16, pôde-se observar a predominância picos referente à Zeólita $\mathrm{Y}\left(\left(\mathrm{Al}_{1.79} \mathrm{Al}_{5} \mathrm{Si}_{10.25} \mathrm{O}_{24}\right)_{96}\right)$ e outros à alumina em sua fase gama. Tais resultados já eram esperados devido à procedência do catalisador [49].

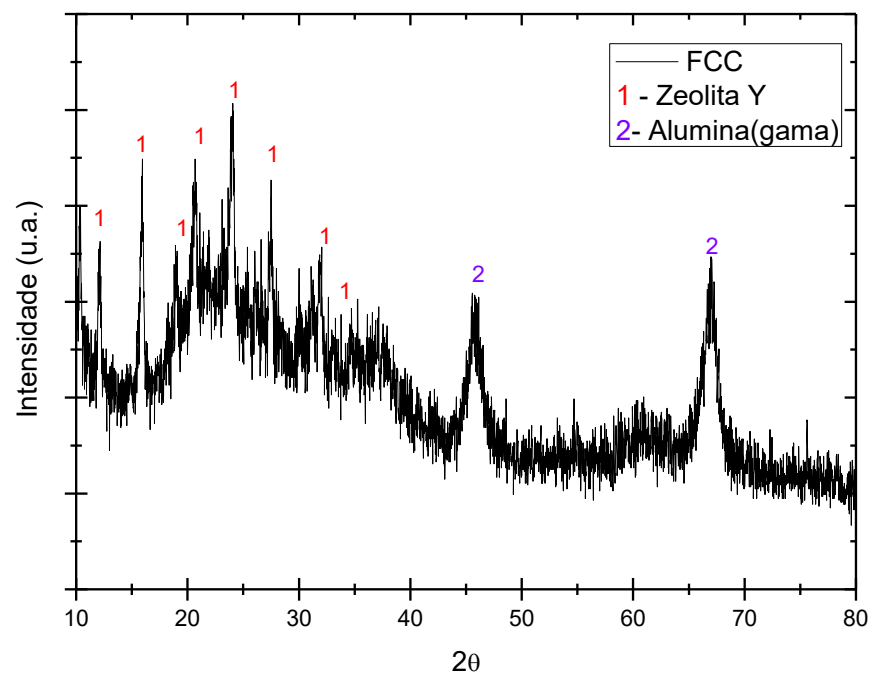

Figura 16. Análise obtida por difração de raios- $X$ do resíduo de catalizador exaurido (ECAT). 


\subsection{Formulação dos vidros}

Como exposto anteriormente no capítulo 3.5, para a produção dos vidros foi realizada previamente análises de fluorescência de raios-X em vidros comerciais para auxiliar na elaboração dos cálculos de formulação do vidro proposto.

As embalagens selecionadas foram de vidros soda-cal incolores utilizados para armazenar perfume. As composições químicas obtidas estão apresentadas na Tabela 7.

Tabela 7. Composição química em porcentagem em massa obtida por fluorescência de raios- $X$ dos vidros de perfume.

\begin{tabular}{l|rrrrrl}
\hline Elementos $\rightarrow$ & $\mathrm{SiO}_{2}$ & $\mathrm{Na}_{2} \mathrm{O}$ & $\mathrm{CaO}$ & $\mathrm{Al}_{2} \mathrm{O}_{3}$ & $\mathrm{Fe}_{2} \mathrm{O}_{3}$ & Outros \\
\hline Vidro 1 & 70,755 & 13,166 & 12,500 & 3,274 & 0,019 & 0,286 \\
\hline Vidro 2 & 70,948 & 12,506 & 12,296 & 3,957 & 0,023 & 0,270 \\
\hline Vidro 3 & 73,655 & 11,749 & 10,804 & 3,563 & 0,026 & 0,203 \\
\hline Vidro 4 & 73,584 & 11,655 & 11,052 & 3,458 & 0,028 & 0,223 \\
\hline
\end{tabular}

Com base nas composições obtidas, foi realizado um ajuste de composição tendo como principal fonte de matéria-prima os resíduos. Desta forma, na Tabela 8 pode-se observar a composição química calculada para o vidro a ser estudado. 
Tabela 8. Composição química em porcentagem em massa calculada do vidro a ser estudado.

\begin{tabular}{|c|c|}
\hline Elementos & Composição calculada \\
\hline $\mathrm{SiO}_{2}$ & 69,900 \\
\hline $\mathrm{Na}_{2} \mathrm{O}$ & 11,600 \\
\hline $\mathrm{CaO}$ & 11,500 \\
\hline $\mathrm{Al}_{2} \mathrm{O}_{3}$ & 4,300 \\
\hline $\mathrm{K}_{2} \mathrm{O}$ & 1,700 \\
\hline $\mathrm{La}_{2} \mathrm{O}_{3}$ & 0,200 \\
\hline MnO & 0,200 \\
\hline $\mathrm{V}_{2} \mathrm{O}_{5}$ & 0,140 \\
\hline $\mathrm{Fe}_{2} \mathrm{O}_{3}$ & 0,160 \\
\hline $\mathrm{NiO}$ & 0,120 \\
\hline Outros & 0,080 \\
\hline
\end{tabular}

\subsection{Resultados obtidos nas primeiras fusões}

A Tabela 9, a seguir representa um resumo dos resultados obtidos nas primeiras tentativas de produção, e seus respectivos parâmetros. 
Tabela 9. Resumo das primeiras tentativas de fusão.

\begin{tabular}{|c|c|c|c|}
\hline Tentativa & Parâmetros & Macrografia & Observações \\
\hline 1a Fusão & $\begin{array}{l}\mathrm{TF}=1400^{\circ} \mathrm{C} \\
\text { Patamar: } 1 \mathrm{~h}\end{array}$ & & $\begin{array}{l}\text { Elevada viscosidade e } \\
\text { massa heterogênea. } \\
\text { Não foi possível verter }\end{array}$ \\
\hline $2^{a}$ a Fusão & $\begin{array}{c}\mathrm{TF}=1500^{\circ} \mathrm{C}(1 \mathrm{~h}) \\
- \text { Prévia } \\
\text { calcinação de } \\
\text { ambos RSI a } \\
900^{\circ} \mathrm{C}(2 \mathrm{~h}) .\end{array}$ & & $\begin{array}{l}\text { Amostra âmbar escuro } \\
\text { e diminuição da } \\
\text { viscosidade, porém } \\
\text { ainda não adequada. }\end{array}$ \\
\hline $3^{\circ}$ Fusão & $\begin{array}{c}\mathrm{TF}=1500^{\circ} \mathrm{C}(1 \mathrm{~h}) \\
- \text { Recozimento } \\
\text { dos RSls a } \\
900^{\circ} \mathrm{C} \text { por } 1 \mathrm{~h} \\
\text { com fluxo de } \mathrm{O}_{2} .\end{array}$ & & $\begin{array}{c}\text { A amostra ficou mais } \\
\text { escura (negra). Não } \\
\text { adequada. }\end{array}$ \\
\hline 4ํㅗ Fusão & $\begin{array}{l}\mathrm{TF}=1500^{\circ} \mathrm{C}(1 \mathrm{~h}) \\
\text { sem } \\
\text { beneficiamento } \\
\text { dos RSIs. }\end{array}$ & & $\begin{array}{l}\text { Amostra satisfatória, } \\
\text { porém, ainda com } \\
\text { elevada viscosidade. }\end{array}$ \\
\hline 5a Fusão & $\begin{array}{l}\mathrm{TF}=1580^{\circ} \mathrm{C}(1) \\
\text { sem } \\
\text { beneficiamento } \\
\text { dos RSIs. }\end{array}$ & 12 & $\begin{array}{l}\text { Amostra satisfatória } \\
\text { para reprodução e } \\
\text { caracterização. }\end{array}$ \\
\hline
\end{tabular}


A seguir serão apresentados alguns resultados obtidos a partir das primeiras tentativas de fusão. Este estudo preliminar visa comparar as mudanças das composições e o processo de homogeneização até a obtenção de amostras adequadas. Em nenhuma dessas amostras foi realizado recozimento, por isso não foram cortadas, somente lixadas e embutidas em resina para melhor visualização.

A primeira fusão, ocorrida a $1400^{\circ} \mathrm{C}$, não proporcionou temperatura suficiente para que a massa fundida fosse vertida em molde. A partir da macrografia exposta na Tabela 9, pode-se observar o escorrimento na parede do cadinho, visualizando a massa fundida heterogênea formada durante a fusão. Desta forma, não foi possível realizar nenhum estudo com esta amostra.

A partir da segunda fusão, ocorrida a $1500^{\circ} \mathrm{C}$ e com prévio recozimento de ambos resíduos a $900^{\circ} \mathrm{C}$ por duas horas, foi possível obter uma amostra âmbar escuro. A imagem da amostra pode ser observada a seguir, na figura Figura 17.

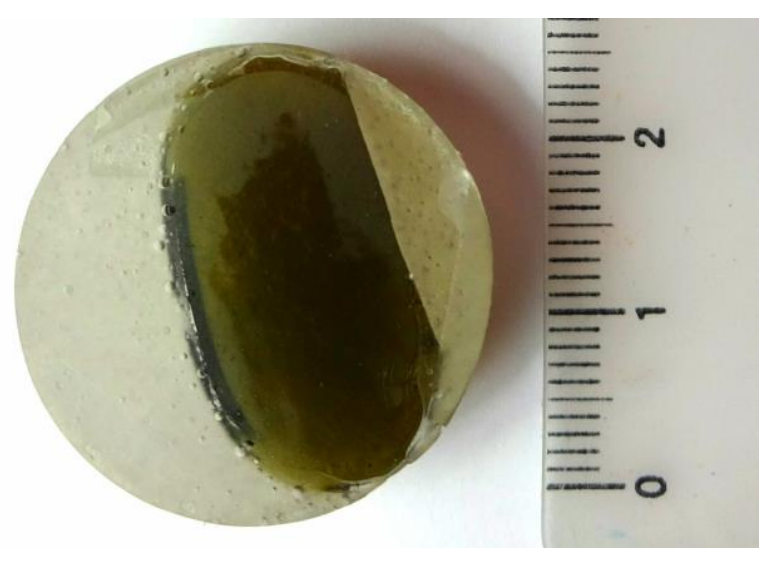

Figura 17. Amostra obtida a partir da segunda fusão.

Com esta amostra foi realizada uma análise de microscopia óptica para avaliação dos defeitos volumétricos. As imagens obtidas podem ser visualizadas a seguir. 


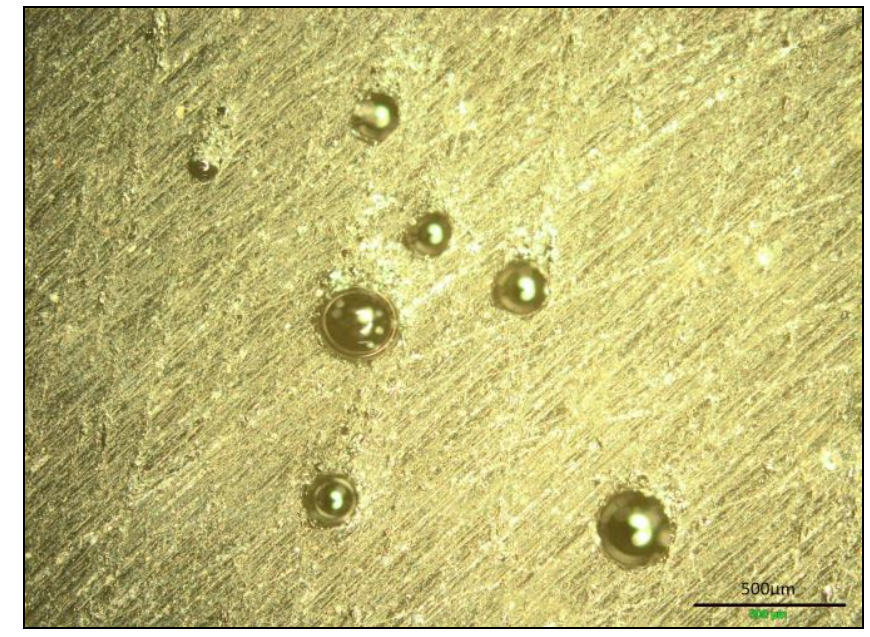

Figura 18. Imagem obtida por microscopia óptica.
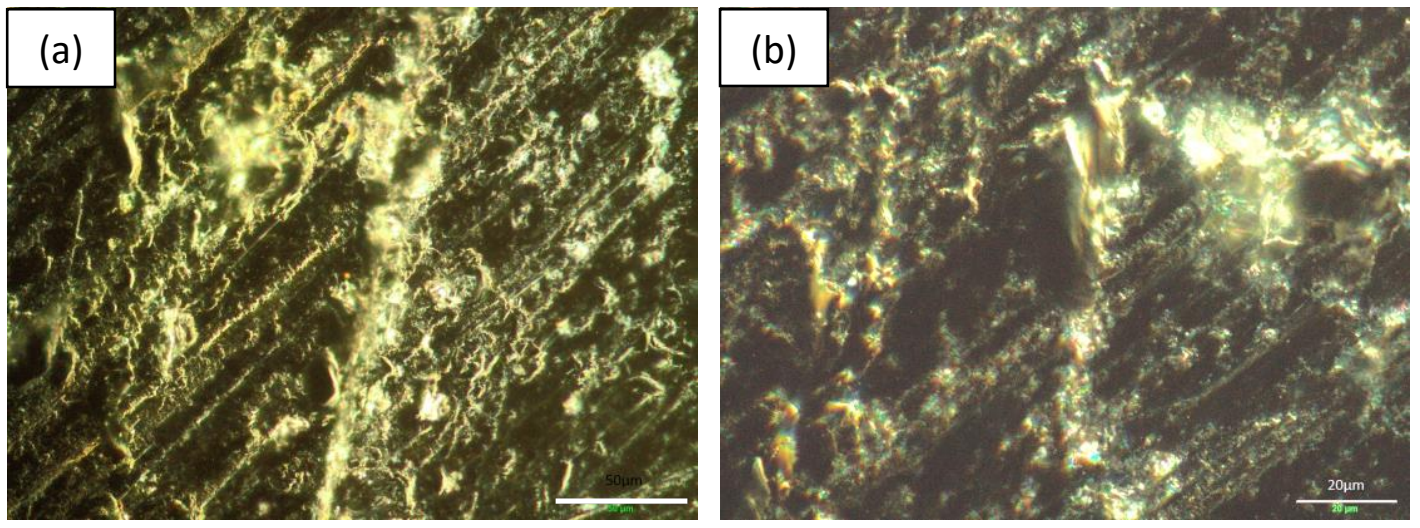

Figura 19. (a) e (b) Imagens obtidas por microscopia óptica.

Como se pode observar a partir das imagens obtidas, a amostra possui bolhas visíveis (Figura 19 (a)) e uma estrutura não uniforme totalmente heterogênea, observada na figura 19 (b).

A partir da terceira fusão, ocorrida a $1500^{\circ} \mathrm{C}$ e com prévio recozimento de ambos resíduos a $900^{\circ} \mathrm{C}$ por uma hora com atmosfera oxidante (fluxo de $\mathrm{O}_{2}$ ), foi possível obter uma amostra negra. A imagem da amostra pode ser observada a seguir, na Figura 20. 


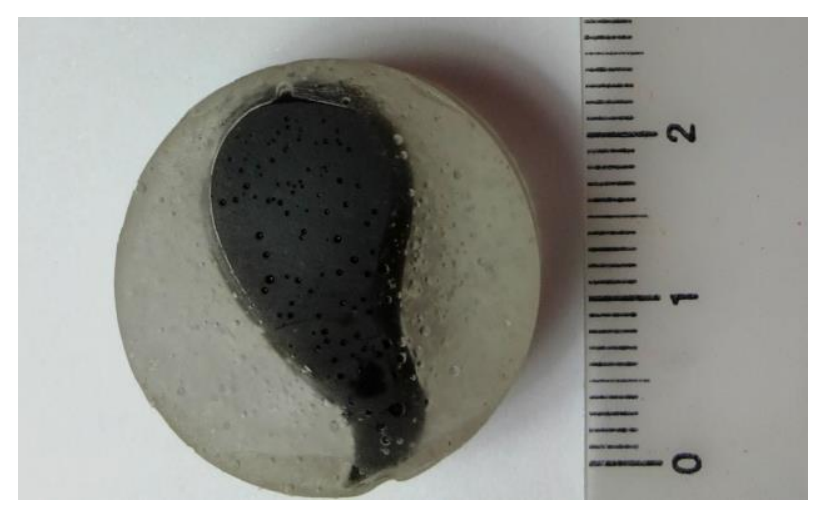

Figura 20. Amostra obtida a partir da terceira fusão.

Assim como a anterior, esta amostra foi submetida à análise de microscopia óptica para avaliação dos defeitos volumétricos. As imagens obtidas podem ser visualizadas a seguir.
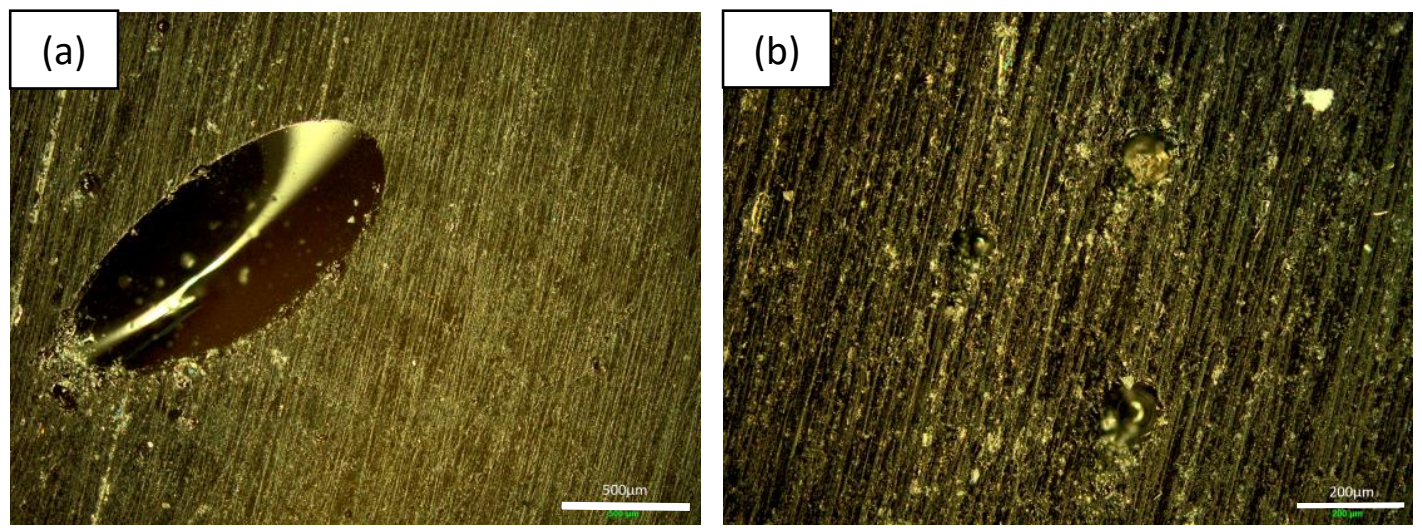

Figura 21. (a) e (b) Imagens obtidas por microscopia óptica. 


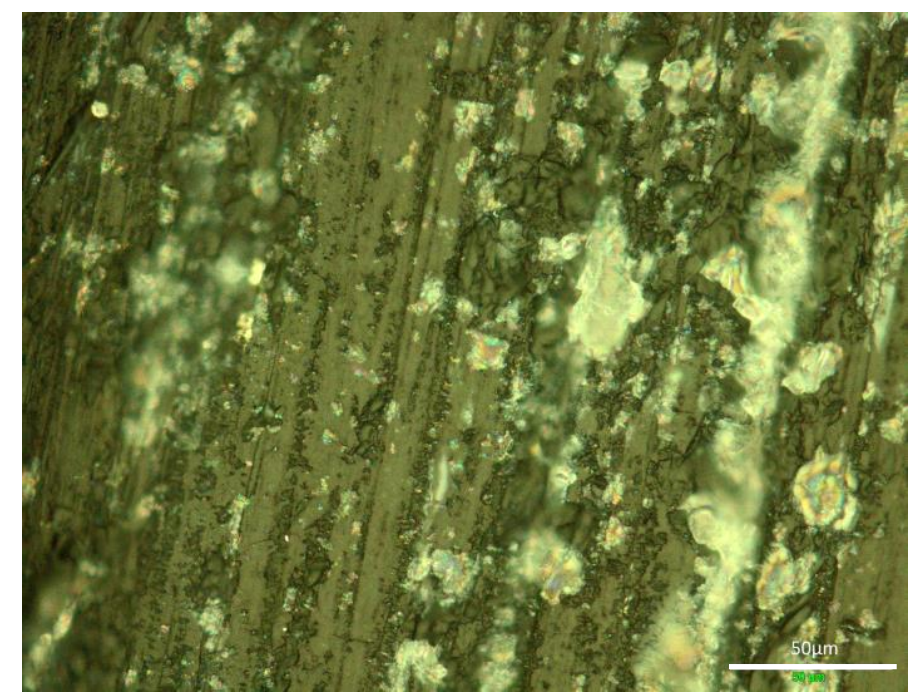

Figura 22. Imagem obtida por microscopia óptica.

A partir das Figuras 21 e 22, a amostra da terceira fusão ainda apresentou bolhas e uma estrutura mais definida do que a amostra da segunda fusão, porém apresentando cristais de quartzo [50].

A quarta fusão, ocorrida a $1500^{\circ} \mathrm{C}$ e sem o prévio recozimento dos resíduos, resultou em uma amostra âmbar, com boa homogeneidade, porém com viscosidade acima do adequado para verter a massa fundida. A imagem da amostra pode ser observada a seguir, na Figura 23.

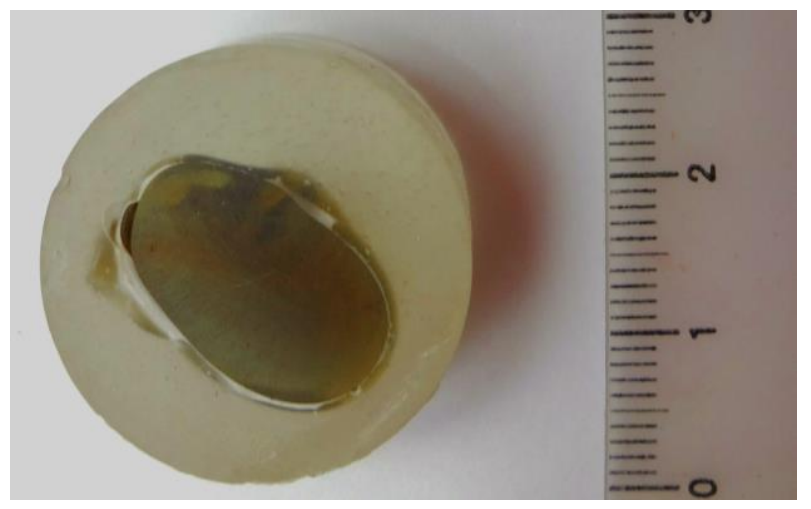

Figura 23. Amostra obtida a partir da quarta fusão.

Foi realizada análise de microscopia óptica da amostra obtida e as imagens podem ser visualizadas a seguir. 


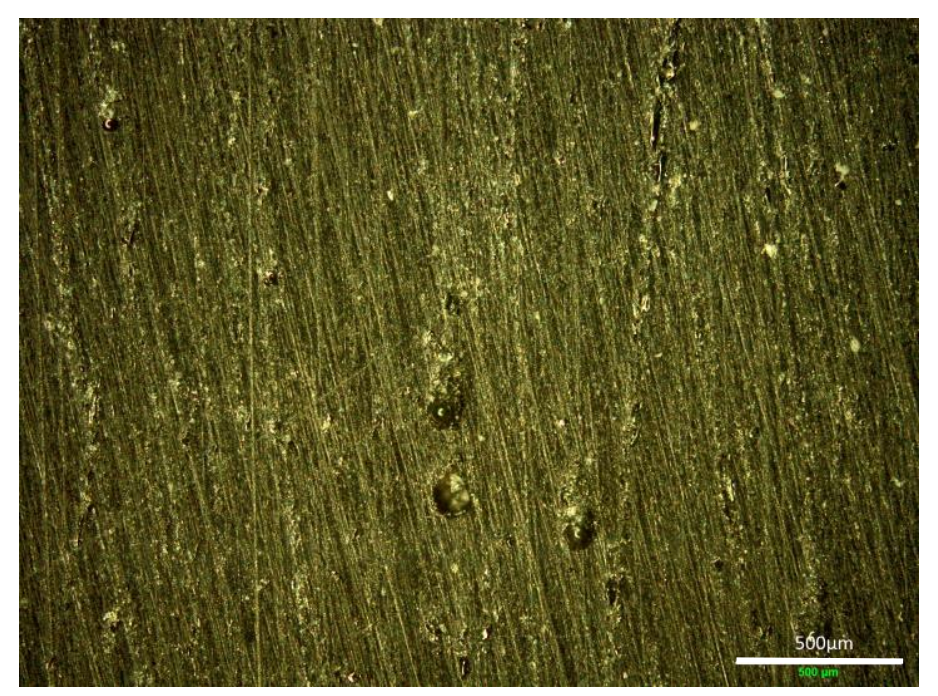

Figura 24. Imagem obtida por microscopia óptica.
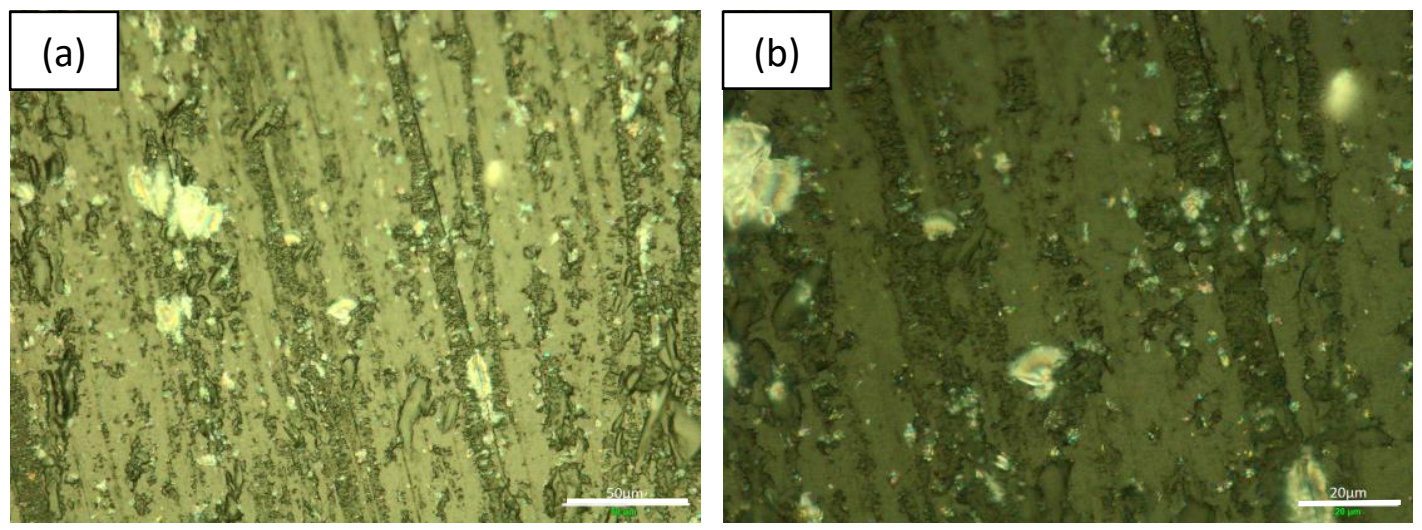

Figura 25. (a) e (b) Imagens obtidas por microscopia óptica.

A partir da Figuras 25 (a) e (b), a amostra da quarta fusão ainda apresentou bolhas, porém de menores dimensões. Provavelmente decorrente da elevada viscosidade. A amostra se mostrou mais homogênea e com menos cristais de quartzo [50].

$\mathrm{Na}$ Tabela 10, pode-se observar as composições químicas elementares obtidas por fluorescência de Raios-X das amostras obtidas entre a segunda e quarta fusão. 
Tabela 10. Composição química (em \% em massa) das tentativas de fusão obtidas por fluorescência de Raios-X.

\begin{tabular}{|c|c|c|c|}
\hline \multirow[b]{2}{*}{ Componentes } & \multicolumn{3}{|c|}{ Amostras } \\
\hline & 2ª Fusão & 3ª Fusão & 4ª Fusão \\
\hline $\mathrm{SiO}_{2}$ & 70,494 & 70,193 & 70,019 \\
\hline $\mathrm{Na}_{2} \mathrm{O}$ & 10,251 & 10,039 & 11,718 \\
\hline $\mathrm{CaO}$ & 11,164 & 11,181 & 9,819 \\
\hline $\mathrm{Al}_{2} \mathrm{O}_{3}$ & 6,150 & 6,113 & 6,109 \\
\hline $\mathrm{K}_{2} \mathrm{O}$ & 1,312 & 1,291 & 1,224 \\
\hline $\mathrm{La}_{2} \mathrm{O}_{3}$ & 0,155 & 0,156 & 0,162 \\
\hline MnO & 0,151 & 0,152 & 0,150 \\
\hline $\mathrm{V}_{2} \mathrm{O}_{5}$ & 0,087 & 0,155 & 0,130 \\
\hline $\mathrm{Fe}_{2} \mathrm{O}_{3}$ & 0,132 & 0,128 & 0,126 \\
\hline $\mathrm{NiO}$ & 0,060 & 0,044 & 0,036 \\
\hline Outros & 0,042 & 0,072 & 0,037 \\
\hline
\end{tabular}

As composições não possuem desvios significantes, de forma que a diferença entre as amostras obtidas é decorrente das temperaturas e parâmetros de processo.

\subsection{Caracterização dos vidros estudados}

Os vidros foram produzidos conforme o procedimento experimental descrito no capítulo 3.5 e as amostras adequadas (provenientes de fusões com parâmetros fixados) foram caracterizadas e seus resultados são apresentados a seguir. 
$\mathrm{Na}$ Tabela 11, são apresentadas as composições químicas das amostras produzidas, obtidas por fluorescência de raios-X. Esta análise foi realizada a fim de verificar a composição obtida correspondia à calculada.

Tabela 11. Composição química obtida por fluorescência de raios-X das amostras obtidas (\% em massa).

\begin{tabular}{|c|c|c|c|c|}
\hline \multirow[b]{2}{*}{ Elementos } & \multicolumn{3}{|c|}{ Amostras } & \multirow[b]{2}{*}{$\begin{array}{l}\text { Composiçãc } \\
\text { Calculada }\end{array}$} \\
\hline & 1CCA-ECAT & 2CCA-ECAT & 3CCA-ECAT & \\
\hline $\mathrm{SiO}_{2}$ & 70,518 & 67,672 & 70,453 & 69,900 \\
\hline $\mathrm{Na}_{2} \mathrm{O}$ & 11,808 & 11,184 & 11,692 & 11,600 \\
\hline $\mathrm{CaO}$ & 9,792 & 10,741 & 10,102 & 11,500 \\
\hline $\mathrm{Al}_{2} \mathrm{O}_{3}$ & 5,985 & 8,498 & 5,843 & 4,300 \\
\hline $\mathrm{K}_{2} \mathrm{O}$ & 1,203 & 1,268 & 1,216 & 1,700 \\
\hline $\mathrm{La}_{2} \mathrm{O}_{3}$ & 0,152 & 0,145 & 0,147 & 0,200 \\
\hline MnO & 0,150 & 0,144 & 0,151 & 0,200 \\
\hline $\mathrm{V}_{2} \mathrm{O}_{5}$ & 0,103 & 0,124 & 0,118 & 0,140 \\
\hline $\mathrm{Fe}_{2} \mathrm{O}_{3}$ & 0,154 & 0,125 & 0,148 & 0,160 \\
\hline $\mathrm{NiO}$ & 0,092 & 0,059 & 0,084 & 0,120 \\
\hline Outros & 0,043 & 0,040 & 0,046 & 0,08 \\
\hline
\end{tabular}

As composições obtidas apresentaram teores próximos à composição calculada inicialmente. Porém, pode-se observar que a amostra 2CCA-ECAT apresentou um teor elevado de $\mathrm{Al}_{2} \mathrm{O}_{3}$ com relação às outras amostras. Este teor foi de decorrente de incorporação indesejada do cadinho utilizado, que foi produzido em laboratório. 
Abaixo pode-se observar as amostras obtidas de coloração âmbar com ausência de bolhas onde a Figura 26 (a) representa a amostra 1CCA-ECAT embutida em resina para análises e a Figura 26 (b) a amostra 2CCA-ECAT, após corte em ISOMET.
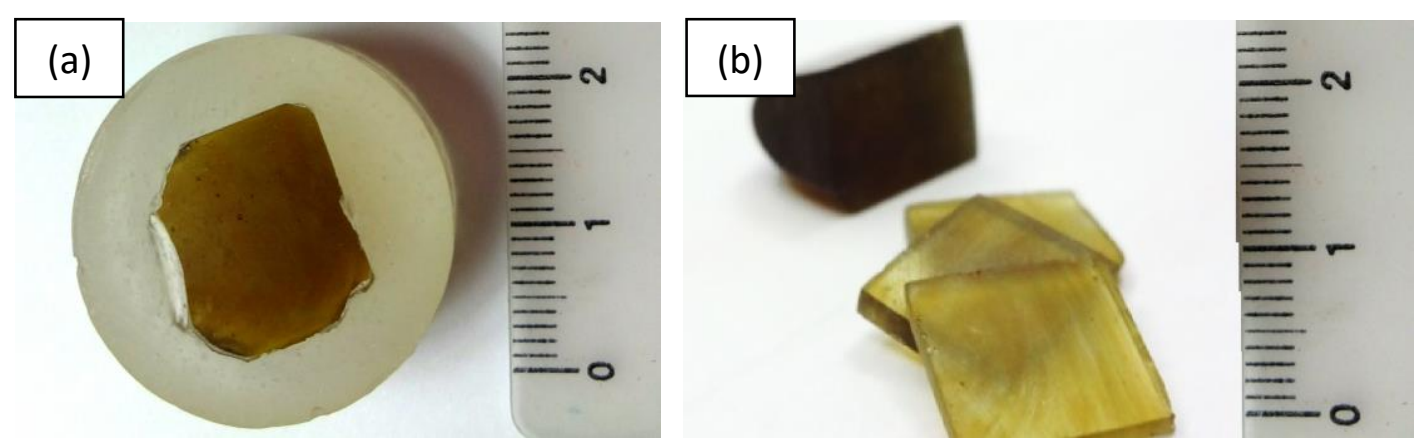

Figura 26 (a) e (b). Amostras 1CCA-ECAT (a) e 2CCA-ECAT (b).

O difratograma obtido através da análise de difração de raios- $X$, observado na Figura 27, valida os parâmetros de produção e recozimento adotado, de forma que foi comprovada a amorficidade da amostra, com a presença do halo característico de materiais amorfos em $2 \theta=25^{\circ}$.

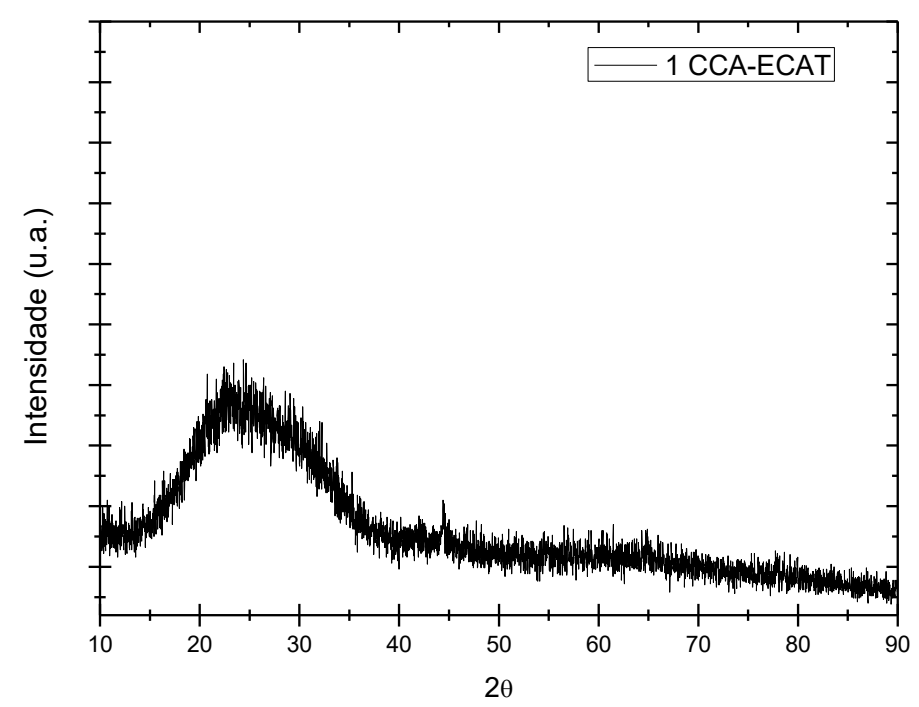

Figura 27. Análise obtida por difração de raios- $X$ do vidro 1CCA-ECAT. 
A partir das análises térmicas diferenciais dos vidros, foi possível calcular a temperatura de transição vítrea $(\mathrm{Tg})$ das amostras, onde foi observada que todas apresentaram $\mathrm{Tg}$ semelhantes, em torno de $555^{\circ} \mathrm{C}$. Este valor era esperado uma vez que literaturas disponíveis apresentaram $\mathrm{Tg}$ de $550^{\circ} \mathrm{C}$ para vidros soda-cal de composição semelhante.

O gráfico obtido através da análise térmica diferencial pode ser observado na Figura 28, com identificação da faixa da Tg.

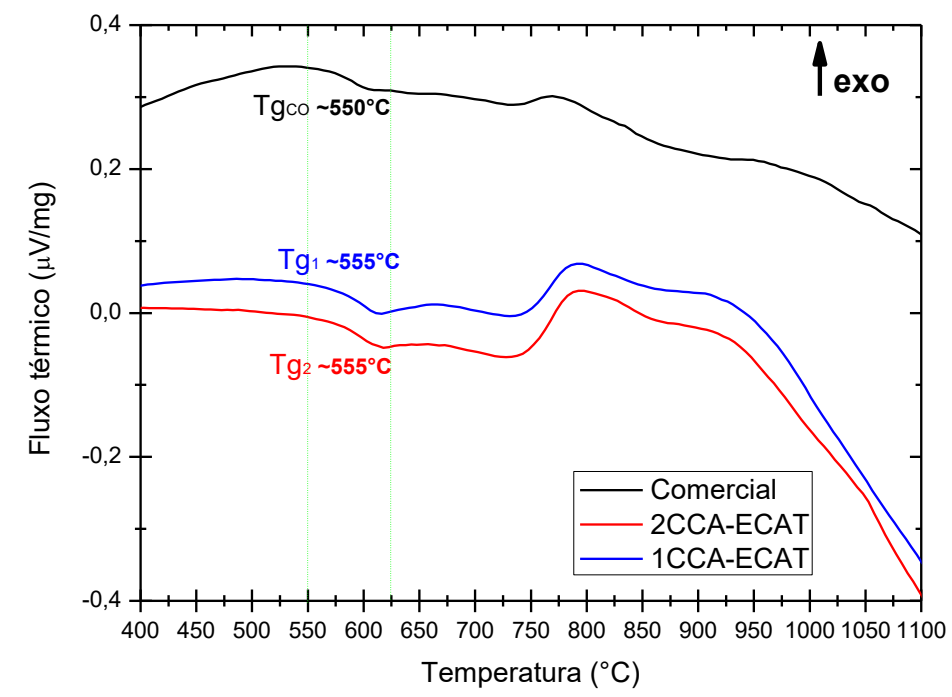

Figura 28. Análise térmica diferencial do vidro comercial (Vidro 1), 2CCA-ECAT e 1CCAECAT.

Tabela 12. Valores atribuídos à temperatura de transição vítrea obtidos a partir da análise térmica diferencial.

\begin{tabular}{c|c}
\hline Amostra & Tg \\
\hline 1CCA-ECAT & $\sim 555^{\circ} \mathrm{C}$ \\
\hline 2CCA-ECAT & $\sim 555^{\circ} \mathrm{C}$ \\
\hline Comercial (Vidro 1) & $\sim 550^{\circ} \mathrm{C}$ \\
\hline
\end{tabular}

O ensaio de resistência hidrolítica foi realizado de acordo com a norma técnica descrita anteriormente na seção 3.4 .9 pelo período de 14 dias e os 
resultados mostraram uma perda mínima de massa (máximo 0,003\%) durante o ensaio, conforme o gráfico exposto na Figura 29.

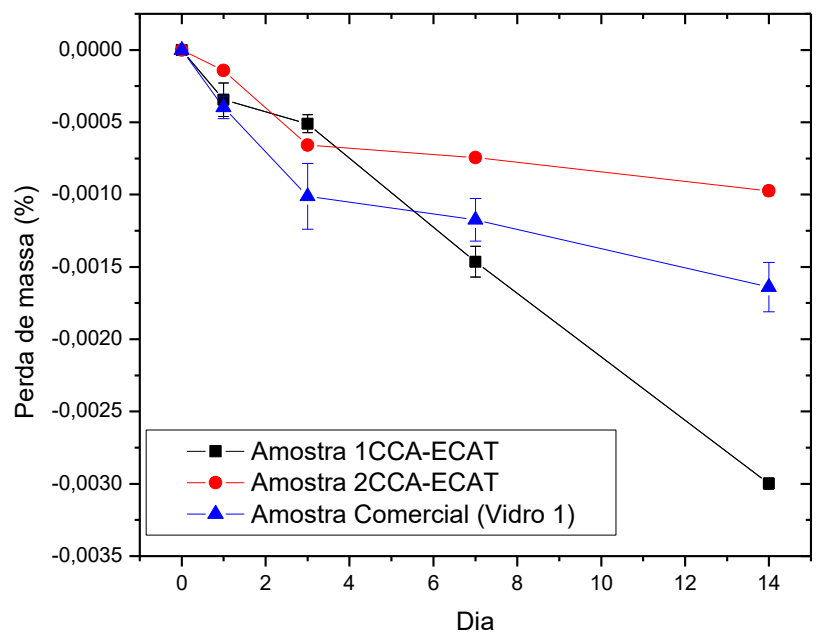

Figura 29. Gráfico da perda de massa durante o ensaio de resistência hidrolítica.

A partir dos resultados de perda de massa obtidos durante o ensaio, foi possível determinar a razão de dissolução das amostras. A Figura 30 representa 0 gráfico da evolução do ensaio de resistência hidrolítica através da variação da razão de dissolução média encontradas nos intervalos de 1, 3, 7 e 14 dias.

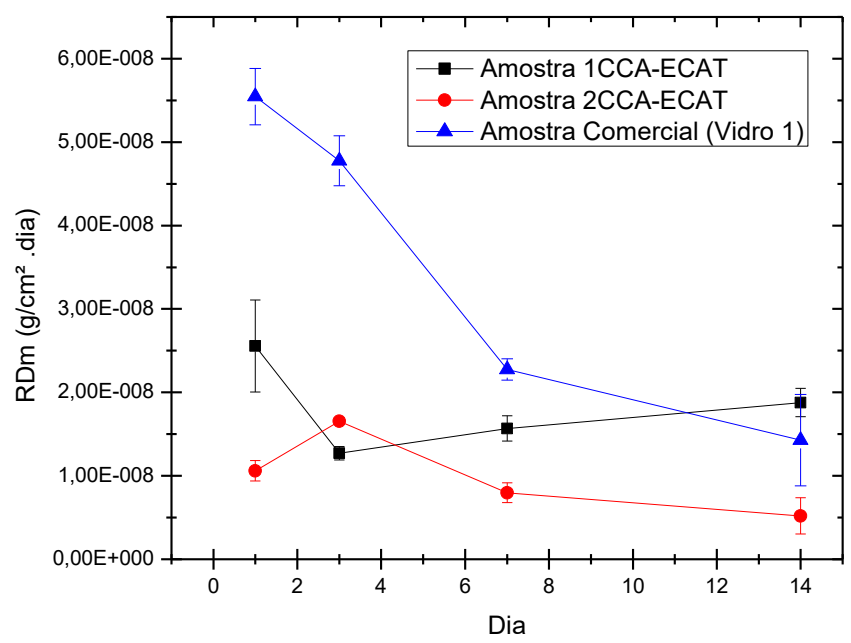


Figura 30. Gráfico da Razão de dissolução média em função dos dias das amostras 1CCA-ECAT, 2CCA-ECAT e Comercial (Vidro 1) do início ao fim do ensaio de lixiviação.

A partir do gráfico da figura 30 pôde-se observar que após o sexto dia de ensaio os valores da razão de dissolução das amostras estabilizaram. Com isso, o ensaio pôde ser interrompido no $14^{\circ}$ dia. Pois, de acordo com a norma, caso os valores não estejam estabilizados no $14^{\circ}$ dia, o ensaio não deve ser interrompido até que a mesma seja obtida, interrompendo-o para medição a cada 7 dias.

A Tabela 13, apresenta ainda os valores das razões de dissolução média obtidas, para melhor interpretação.

Tabela 13. Razões de dissolução média das amostras 1CCA-ECAT, 2CCAECAT e Comercial (Vidro 1), após 14 dias imersos em água destilada à $90^{\circ} \mathrm{C}$.

\begin{tabular}{c|c}
\hline Amostra & $\mathbf{R D}_{\mathbf{m}}$ \\
\hline 1CCA-ECAT & $1,769340 \times 10^{-8} \mathrm{~g} / \mathrm{cm}^{2} \times$ dia \\
\hline 2CCA-ECAT & $1,007454 \times 10^{-8} \mathrm{~g} / \mathrm{cm}^{2} \times$ dia \\
\hline Comercial (Vidro 1) & $3,506475 \times 10^{-8} \mathrm{~g} / \mathrm{cm}^{2} \times$ dia \\
\hline
\end{tabular}

Os resultados obtidos garantem a integridade das amostras produzidas, de maneira que foi possível obter uma razão de dissolução média da ordem de 10${ }^{8} \mathrm{~g} /\left(\mathrm{cm}^{2} \cdot \mathrm{min}\right)$ para ambas as amostras testadas. Este resultado é considerado bom visto que a amostra comercial apresentou resultados na mesma ordem de grandeza.

Pode-se observar que a amostra 2CCA-ECAT, que possui maior teor de $\mathrm{Al}_{2} \mathrm{O}_{3}$, apresentou maior razão de dissolução. Este fato já era esperado uma vez que este composto, mesmo em pequenas quantidades, aumenta a resistência hidrolítica do vidro.

Após o ensaio de lixiviação, foi realizada análise de fluorescência de raios- $X$ da amostra 1CCA-ECAT, a fim de comparar sua composição antes e após o ensaio, e avaliar se houve alguma perda específica. 
$\mathrm{Na}$ Figura 31, observa-se um gráfico de barras, no qual a cinza chumbo representa os valores de composição relativa obtidos antes do ensaio (pré-lixiviação) e a parte cinza claro, após o ensaio (pós-lixiviação).

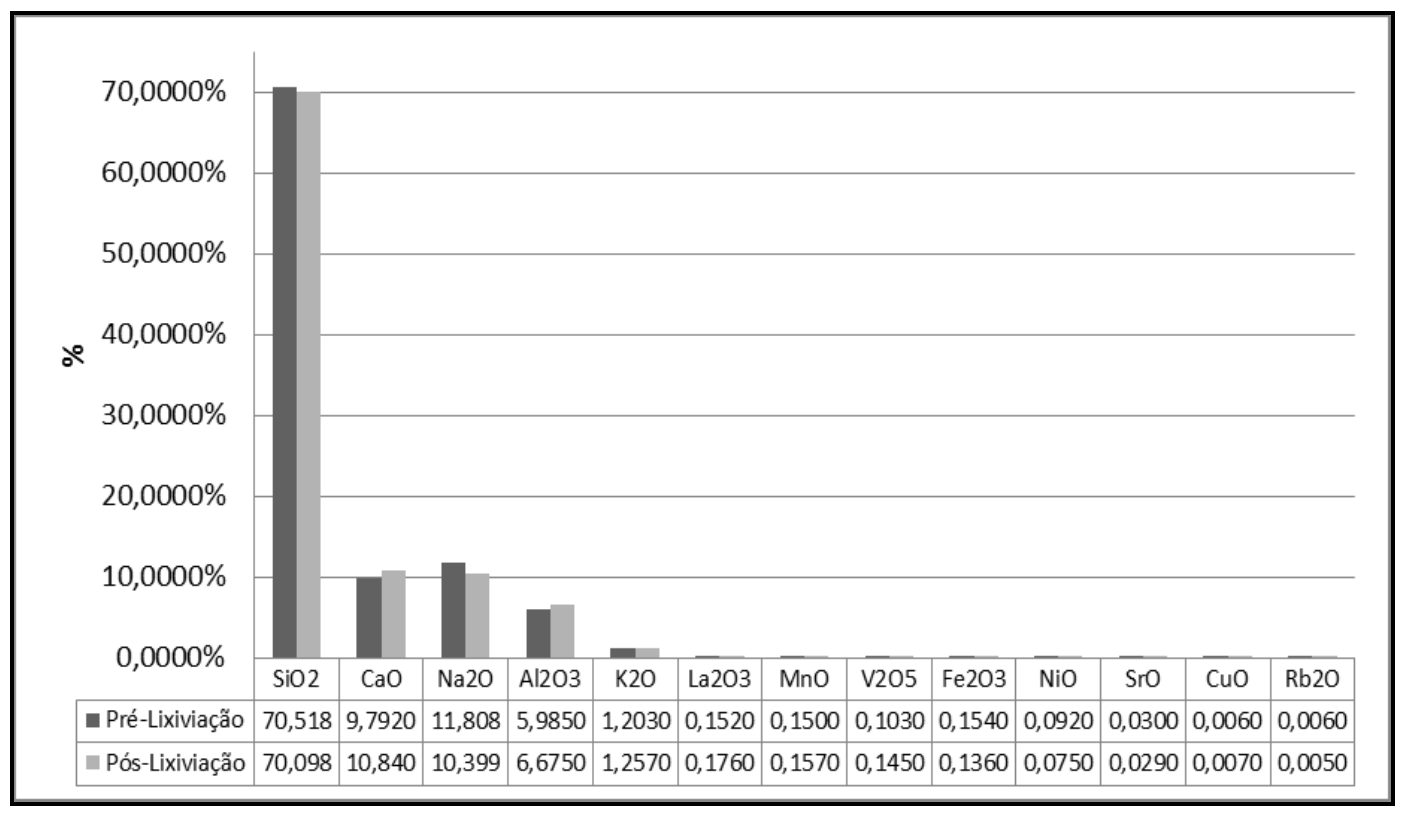

Figura 31. Diagrama comparativo contendo a composição química relativa da amostra 1CCA-ECAT antes e após o ensaio de lixiviação.

Já na Figura 32, pode-se observar a diferença absoluta obtida entre as composições avaliadas.

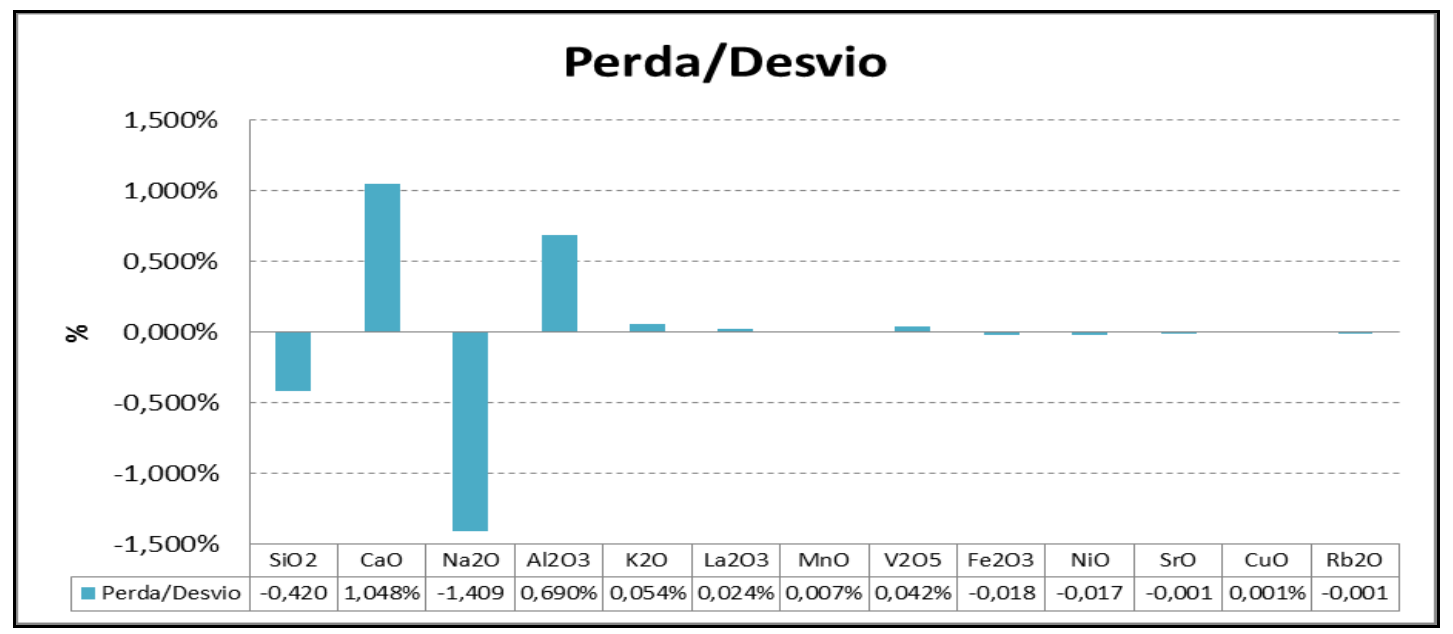

Figura 32. Diferença obtida entre as composições Pré e Pós lixiviação da amostra 1CCA-ECAT. 
Verifica-se que não houve perda significante dos compostos, comprovando que a amostra não sofreu um ataque intenso, apenas de primeiro estágio com a perda de teores de $\mathrm{Na}_{2} \mathrm{O}$, e que não houve lixiviação seletiva de nenhum íon de metal de transição.

Após, foi realizado um estudo por microscopia óptica da amostra 1CCA-ECAT antes e após o ensaio de lixiviação. Os resultados obtidos por microscopia óptica são apresentados a seguir.

A Figura 33 (a) apresenta a micrografia da amostra 1CCA-ECAT antes do ensaio de lixiviação e a Figura 33 (b) após o ensaio de lixiviação.
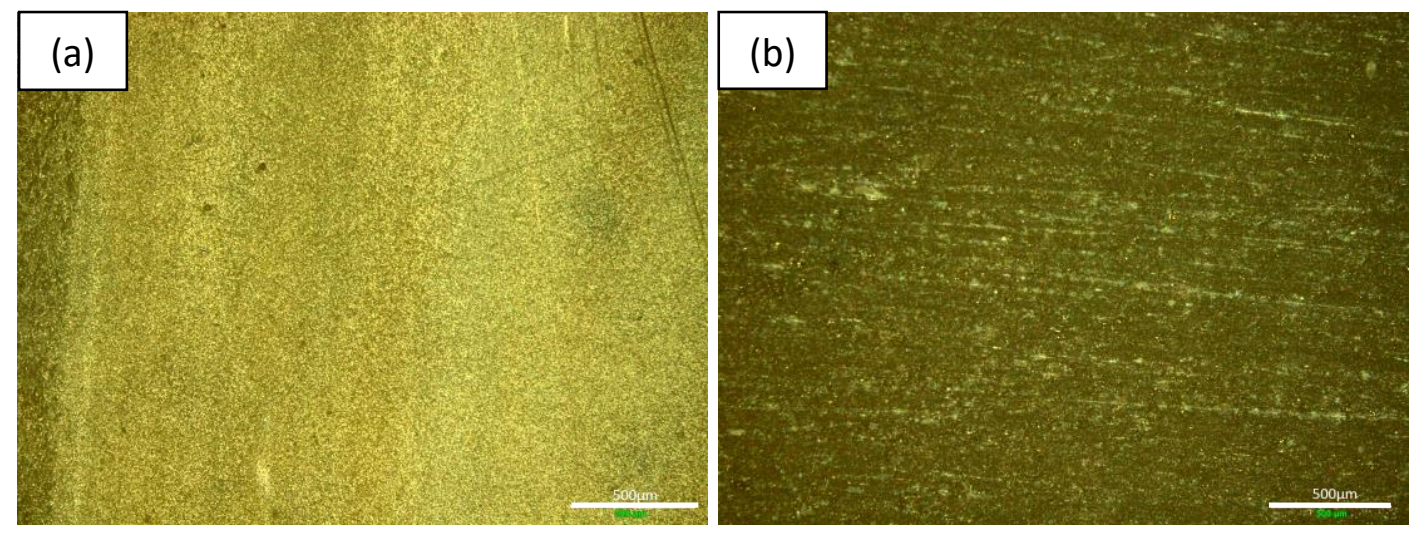

Figura 33. Imagens obtidas por microscopia óptica. (a) Amostra 1CCA-ECAT antes do ensaio de lixiviação; (b) Amostra 1CCA-ECAT após o ensaio de lixiviação.

A partir da Figura 33, observa-se uma mudança na superfície da amostra após a lixiviação. Tal mudança é decorrente da lixiviação inicial do vidro quando em contato com um meio líquido.

Neste estágio, há a troca iônica entre íons alcalinos $\left(\mathrm{Na}^{+}, \mathrm{K}^{+}\right.$, por exemplo), como observado na análise química realizada após a lixiviação, indicando o desvio apenas do composto $\mathrm{Na}_{2} \mathrm{O}$. 
A Figura 34 apresenta micrografias das mesmas amostras, porém com aumentos diferentes, conforme observado abaixo.
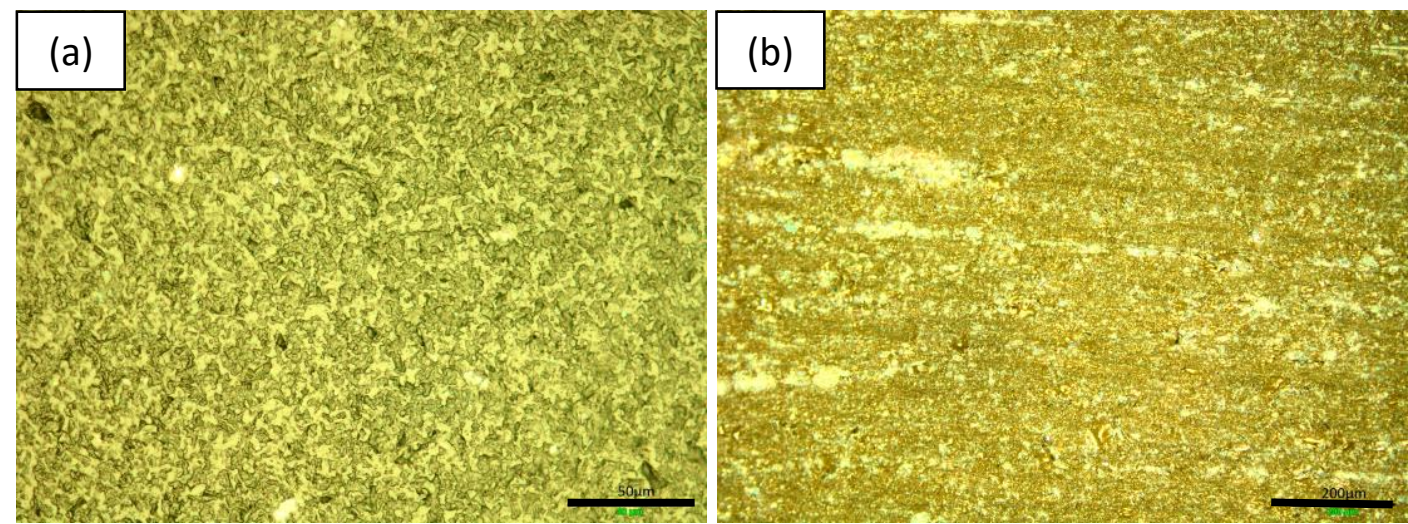

Figura 34. (a) e (b) Imagens obtidas por microscopia óptica da amostra 1CCAECAT antes (a) e após (b) o ensaio de resistência hidrolítica.

Já a Figura 35 (a), apresenta a amostra 1CCA-ECAT antes do ensaio de resistência hidrolítica e a Figura 35 (b), após o ensaio em outro ponto da amostra.

Observa-se uma mudança significativa melhor a lixiviação de íons alcalinos, onde há um aumento da área superficial do vidro, deixando uma camada rica em elementos formadores, neste caso $\mathrm{Si}$, de forma que é possível observar vários cristais na micrografia.
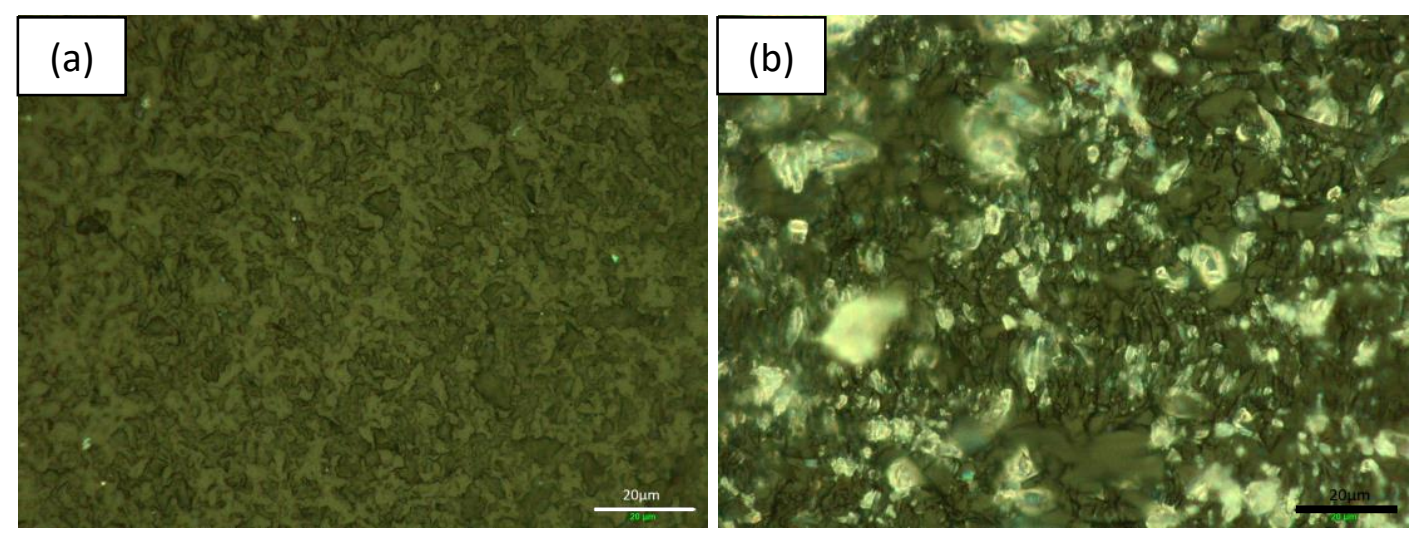

Figura 35. (a) e (b) Imagens obtidas por microscopia óptica da amostra 1CCAECAT antes (a) e após (b) o ensaio de resistência hidrolítica. 
Os resultados obtidos com a técnica de espectrometria de transmitância e absorbância no UV-VIS são apresentados a seguir.

A Figura 36 apresenta os espectros de absorção óptica no comprimento de onda visível da amostra comercial e da 1CCA-ECAT.

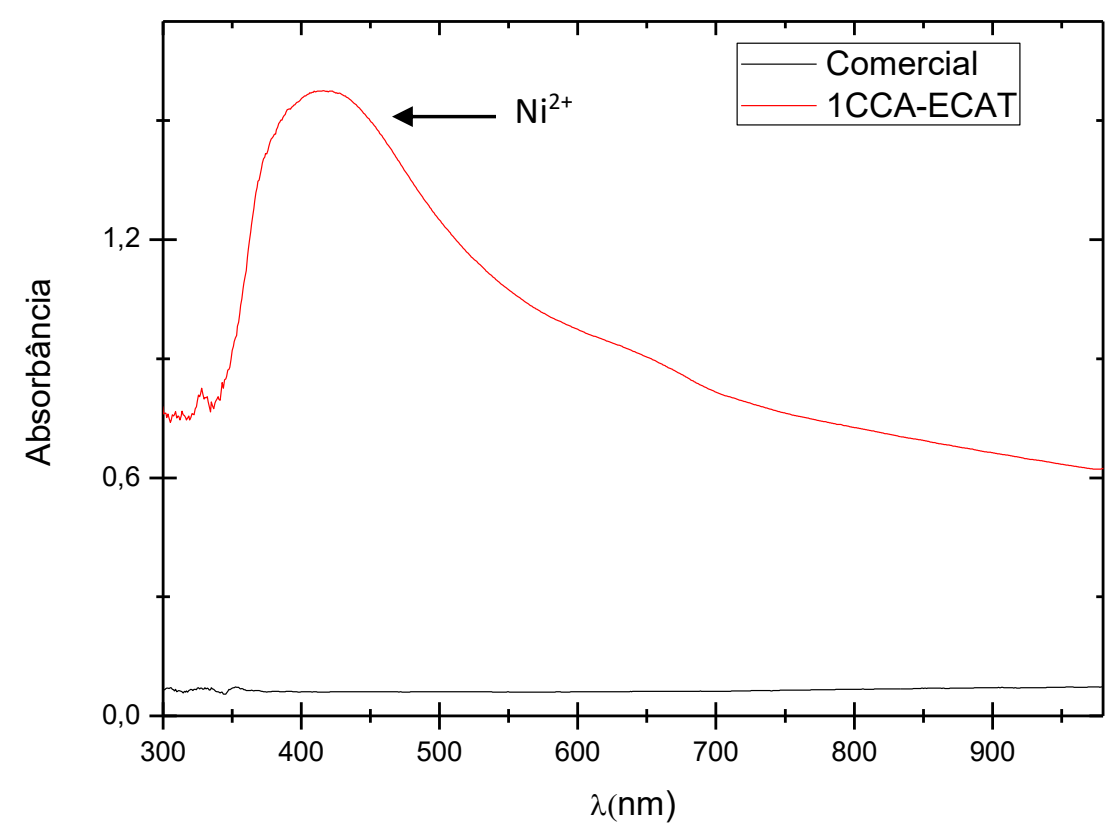

Figura 36. Espectros de absorbância óptica das amostras comercial e 1CCA-ECAT.

Nota-se que o espectro do vidro comercial apresentou absorbância praticamente nula, por ser incolor, correspondendo ao branco que não promove absorção.

Já a amostra 1CCA-ECAT possui absorbância mais elevada com relação aos outros, além de revelar picos característicos que ocorrem quando há a presença de metais de transição específicos e/ou terras raras.

Neste caso, como já visto anteriormente, a composição química do ECAT possui metais de transição devido à contaminação do catalisador virgem com o processo de craqueamento, e cada metal tem espectros característicos, é possível identificar os componentes referentes aos picos característicos identificados. Tais 
componentes são, na verdade, aqueles que no comprimento de onda visível se manifestam resultando na cor que pode ser observada na amostra a olho nu.

A princípio, observando a análise de fluorescência de raios- $X$ do ECAT, existem quatro elementos identificados como metais de transição em sua composição, sendo eles: lantânio, vanádio, ferro e níquel.

Entretanto, analisando o espectro obtido por absorção óptica, visualiza-se um pico característico em $450 \mathrm{~nm}$ que é correspondente ao íon de $\mathrm{Ni}^{2+}$. E que no visível se manifesta na cor âmbar ("amarelo amarronzado", segundo Navarro) [33].

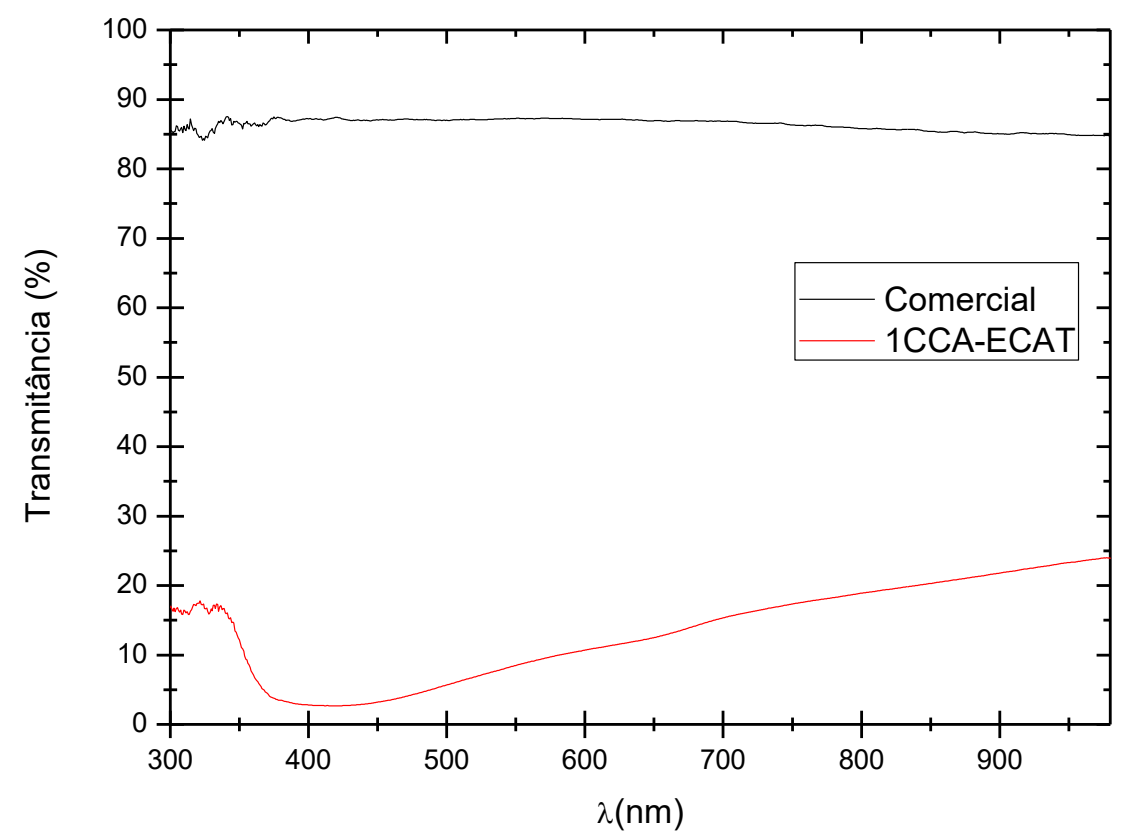

Figura 37. Espectros de transmitância óptica das amostras comercial e 1CCA-ECAT.

A partir dos espectros de transmitância óptica nota-se que a transmitância do vidro comercial varia em torno de $83 \%$ nas mesmas faixas do espectro. Já o vidro 1 CCA-ECAT, varia na faixa dos $18 \%$ na mesma faixa do espectro e chega próximo a $25 \%$ no início do infravermelho.

As amostras obtidas se mostraram adequadas para aplicações que exigem menor transmissão luminosa, como por exemplo, vidros de embalagens coloridas em geral, foco deste trabalho. 
Com os resultados obtidos das análises de absorção óptica é possível representar as cores dos vidros em um sistema de coordenadas conhecido como CIE. Tal representação compara a diferença de cores das amostras de um modo mais representativo.

Abaixo pode-se observar o diagrama do sistema CIE com as coordenadas das amostras caracterizadas, numeradas como 1 e 2 , representando o vidro comercial e a amostra 1CCA-ECAT.

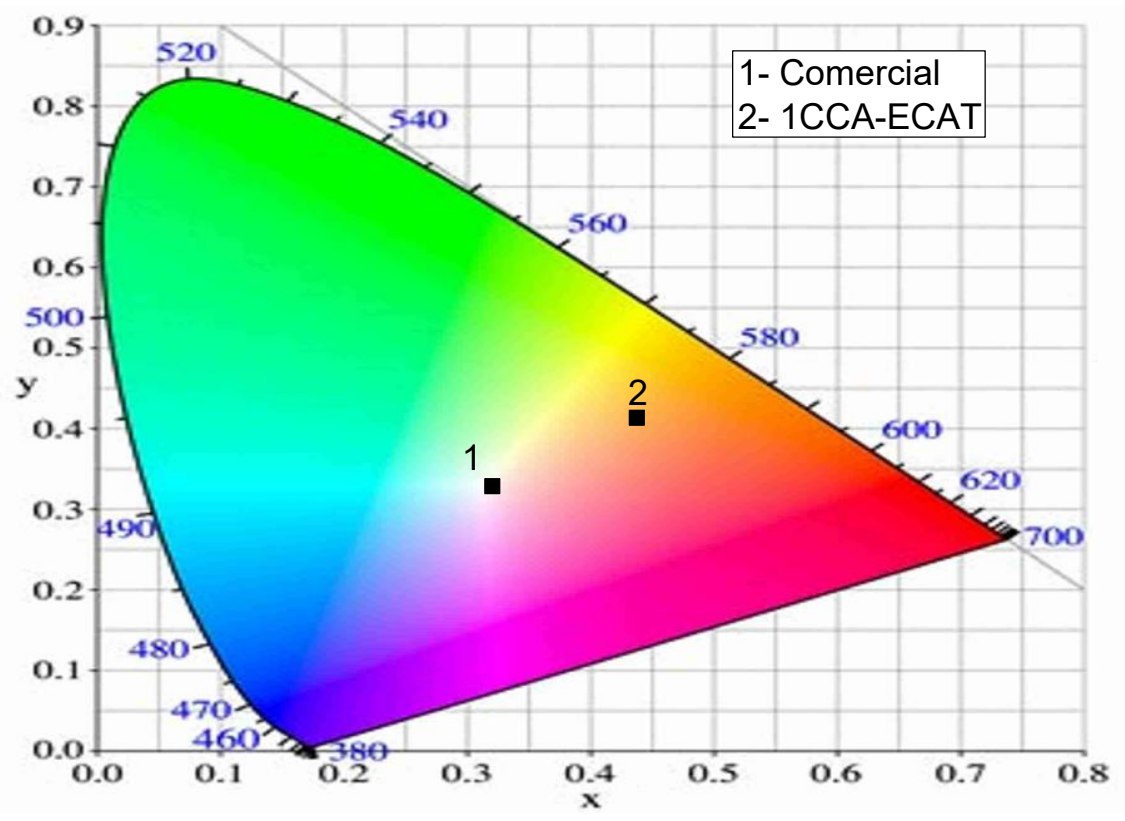

Figura 38. Coordenadas colorimétricas no sistema CIE.

No diagrama podemos observar que o vidro comercial possui ponto no centro do diagrama que representa o branco, e o vidro 1CCA-ECAT, no âmbar. Estes dados são validados juntamente com o que foi apresentado nos espectros de transmitância e absorbância anteriormente.

Em adição, a Figura 39 confirma as medidas colorimétricas realizadas representando macrografias das amostras 1CCA-ECAT, 2CCA-ECAT e comercial. 


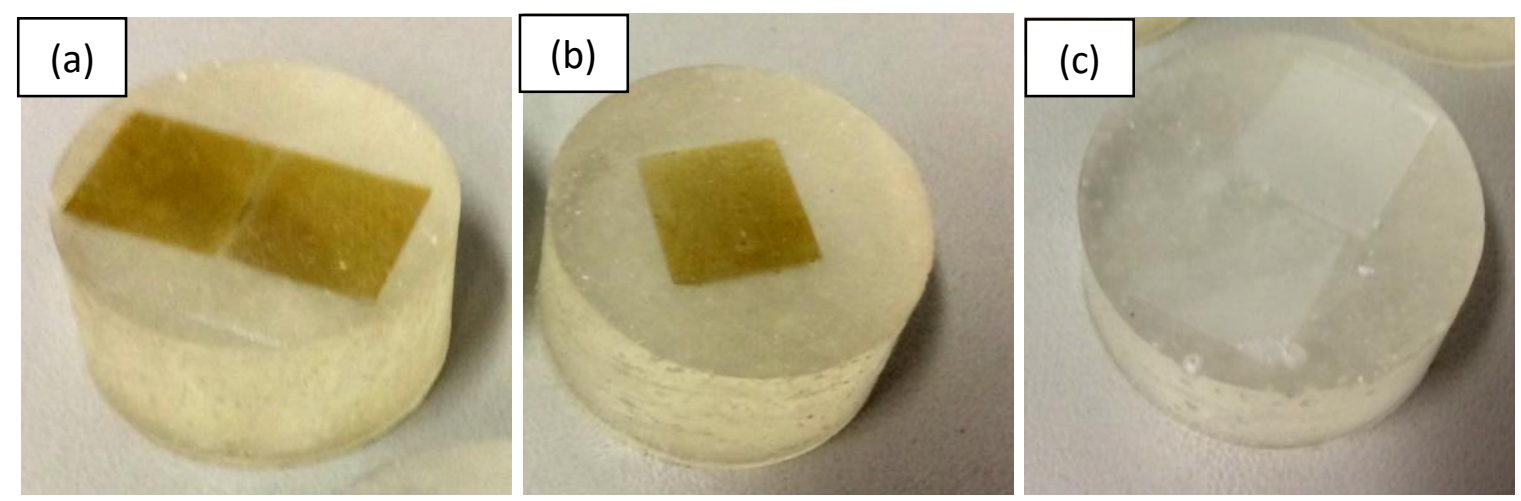

Figura 39. Macrografia das amostras 1CCA-ECAT, 2CCA-ECAT e Comercial embutidas em resina. 


\section{CONCLUSÕES}

O bom conhecimento dos resíduos propostos é fundamental para sua utilização como matéria prima para fabricação de vidros. As análises de ambos confirmam estudos realizados anteriormente, e qualificam ambos os resíduos como fonte de $\mathrm{SiO}_{2}$ e $\mathrm{Al}_{2} \mathrm{O}_{3}$ para produção de vidros comerciais.

Os estudos realizados neste trabalho mostraram que tais resíduos podem ser utilizados como matéria-prima na fabricação de vidros, não precisando de tratamento ou processamento intermediário. Isto se faz importante diante da cadeia produtiva, pois reduziria os custos envolvidos na produção viabilizando a alternativa de seu uso.

A metodologia adotada para a fabricação de vidros se mostrou eficiente, de forma que a sílica e alumina presente na composição final tiveram como precursores os próprios resíduos.

Este trabalho apresentou os resultados experimentais satisfatórios comprovando a viabilidade incorporação dos RSIs CCA e ECAT em vidros silicatos soda-cal, permitindo a incorporação em torno de $77 \%$ em massa de resíduos na composição final do vidro. 


\section{SUGESTÕES PARA TRABALHOS FUTUROS}

- Caracterização de vidros comerciais âmbar para comparação com os resultados obtidos.

- Realizar ensaios de resistência química em meio alcalino e ácido.

- Investigação da influência da cristobalita durante a fusão, por ser mais leve e dissolver com maior dificuldade.

- Estudo de possível comportamento corrosivo durante a fusão (cadinho/refratário).

- Caracterização a partir de técnicas mais robustas como a espectroscopia no infravermelho na transformada de Fourier (FT-IR), Espectroscopia Raman e ressonância nuclear magnética de estado sólido, (RMN) afim de avaliar em nível estrutural o vidro obtido.

- E buscar novas composições visando ampliar a gama de vidros comerciais que podem ser produzidos a partir dos RSIs em questão.

- Estudo de adaptações para produção em escala industrial. 


\section{REFERÊNCIAS BIBLIOGRÁFICAS}

[1] HECK, Stefan; ROGERS, Matt. Resource Revolution. $1^{\text {a }}$ ed. Seattle: Amazon Publishing, 2014.

[2] BRASIL. INSTITUTO DE PESQUISA ECONÔMICA APLICADA. Diagnóstico dos Resíduos Sólidos Industriais. Brasília, 2012.

[3] ASSOCIAÇÃO BRASILEIRA DE NORMAS TÉCNICAS. NBR 1004: resíduos sólidos - classificação. Rio de Janeiro, 1987.

[4] MAIA, Mazzon Roque; TEIXEIRA, Larissa. Desafios e perspectivas da produção sustentável de biodiesel no semiárido nordestino, v. 5, n. 2006, p. 1-16, 2010.

[5] BRASIL. DEPARTAMENTO NACIONAL DA PRODUÇÃO MINERAL. Anuário Mineral Brasileiro. Brasília, 2010.

[6] CARLOS, Luiz; FRANCISCO, José; MOTTA, Marciano, Panorama Setorial Minerais Industriais, v. 5, n. Quadro 1, p. 37-40, 2000.

[7] BRASIL. Ministério do meio ambiente. Política nacional dos resíduos sólidos. Brasília, 2012.

[8] MAYER, Flávio Dias. Aproveitamento da casca de arroz em uma micro central termoelétrica - Avaliação dos impactos econômicos e ambientais para o setor arrozeiro do Rio Grande Do Sul. 2009. Dissertação (Mestrado em Engenharia de Produção) Universidade Federal de Santa Maria, Rio Grande do Sul.

[9] FOLETTO, Edson. Luiz, Ronaldo Hoffmann. Aplicabilidade Das Cinzas Da Casca de Arroz. Química Nova 28(6):1055-60, 2005. 
[10] NATARAJAN. E. et al. Experimental determination of bed agglomeration tendences of some common agricultural residues in fluidized bed combustion and gasification.

[11] COMPANHIA NACIONAL DE ABASTECIMENTO. Acompanhamento de safra brasileira: grãos, Quarto levantamento, janeiro 2015. Brasília, 2015.

[12] LEITE, Luiz Fernando; DIAS, Luís Eduardo Duque; ANTUNES, Adelaide Maria De Souza, Desenvolvimento tecnológico na indústria do petróleo: o ambiente organizacional e seus aspectos habilitadores e inibidores da inovação. Revista de Administração, v. 41, n. 3, p. 301-314, 2006.

[13] PRADO, Ulisses Soares do; MARTINELLI, J. R.; SILVEIRA, J. A. da, SILVA, L. L. Utilização do refugo de catalisador usado nas Unidades Petroquímicas de Craqueamento Catalítico Fluído (FCC) na composição de fritas cerâmicas. In: Congresso Brasileiro de Cerâmica, 55‥, 2011, Pernambuco, Anais, Associação Brasileira de Cerâmcia, 2011.

[14] TUSCHAROENA S., KAEWKHAO J., LIMSUWAN P., CHEWPRADITKULA W. Structural, Optical and Radiation Shielding Properties of $\mathrm{BaO}-\mathrm{B}_{2} \mathrm{O}_{3}-$ Rice Husk Ash Glasses. Procedia Engineering, v. 32, p.734-739, 2011.

[15] KAEWKHAO J., LIMSUWAN, P. Utilization of rice husk fly ash in the color glass production. Procedia Engineering, v.32, p. 670-675, 2012.

[16] ESCARDINO A., AMOROS J. L., MORENO A., SANCHEZ E. Utilizing the used catalyst from refinery FCC units as a substitute for kaolin in formulating ceramic frits. Waste Management \& Research, v.13, p.569-578, 1995. 
[17] TASHIMA M.M., AKASAKI J.L., CASTALDELLI V.N., SORIANO L., MONZÓ J., PAYÁ J., BORRACHERO M.V. New geopolymeric binder based on fluid catalytic cracking catalyst residue (FCC). Materials letters, v. 80, p.50-52, 2012.

[18] VAN, Viet-Thien-an, RÖßLER, C., BUI, Danh-Dai, LUDWIG, Horst-Michael. Pozzolanic reactivity of mesoporous amorphous rice husk ash in portlandite solution. Construction and Building Materials, v.59, p.111-119, 2014.

[19] BOUZÓN, N., PAYÁ J., BORRACHERO M.V., SORIANO L., TASHIMA M.M., MONZÓ J. Refluxed rice husk ash/NaOH suspension for preparing alkali activated binders. Materials letters, v. 115, p.72-74, 2014.

[20] PIRELLI. Pirelli comemora mais de um milhão de pneus, São Paulo, 29 jan. 2015. Disponível em <http://www.pirelli.com/tyre/br/pt/news/2015/01/29/pirellicomemora-mais-de-um-milhao-de-pneus/>. Acesso em: fevereiro, 2015.

[21] AlVeZ, O. L; GIMEnEZ, I. F.; MAZALI, I, O. Vidros. Química Nova. 2001. Edição especial cadernos temáticos.

[22] SHELBY, J.E. Introduction to Glass Science and Technology. 2o ed. Cambridge: The Royal Society of Chemistry, 2005.

[23] ZACHARIASSEN, W. H., The atomic arrangement in glass. Journal of American Chemistry Society, v. 54, p. 3841-3851, 1932.

[24] GUPTA, P.K. Non-crystalline solids: Glasses and Amorphous solids. Journal of Non-Crystalline Solids, v.195, p. 158-164, 1996.

[25] CACHO, V.D. D. Produção e Caracterização de Guias de Onda de telureto e germanato para aplicações em optoeletrônica. 2010. Tese (Doutor em Engenharia Microeletrônica). Escola Politécnica da Universidade de São Paulo, São Paulo. 
[26] VARSHNEYA, A.K. Fundamentals of inorganic Glasses, $1^{\text {a }}$ ed. Academic Press, 1994.

[27] GOLDSCHMIDT, V.M., Crystal structure and chemical constitution. Trans. Faraday Soc., v. 25, p. 253-283, 1929.

[28] STANWORTH, J. E. Oxide Glass Formation from the melt. Journal of Ceramic Society, v. 54, p. 61-63, 1971.

[29] BABISK, M. P. Desenvolvimento de vidros sodo-cálcicos a partir de resíduos de rochas ornamentais. 2009. Dissertação (Mestre em Ciências - Ciências dos Materiais). Instituto Militar de Engenharia, Rio de Janeiro.

[30] AKERMAN, M. Natureza Estrutura e Propriedades do Vidro. Saint Gobain: Centro Técnico de Elaboração do Vidro, 2000.

[31] NASSAU, K. The Physics and Chemistry of Color: The fifteen Causes of Color. $1^{\underline{a}}$ ed. Wiley-Interscience: p. 504. 1983.

[32] SALMANG, H.; SÁNCHEZ-CONDE, M. C.; ALEIXANDRE, V. Fundamentos físico-químicos de la fabricación del vidrio. 1ํㅡㄹ ed. Madrid Aguilar: 1962.

[33] NAVARRO, J.M. F. El vidrio. Consejo Superior de Investigaciones Científicas. Fundación Centro Nacional del Vidrio. 2.ed. España.1991.

[34] VIEIRA, Heveline, Avaliação da cristalização e durabilidade química de vidros niobofosfatos visando a imobilização de rejeitos radioativos. 2008. Dissertação (Mestrado em Tecnologia Nuclear - Materiais). Instituto de Pesquisas Energéticas e Nucleares, São Paulo.

[35] DA SILVA, Antonio Carlos, Incorporação de resíduo galvânico em vidro silicato obtido a partir de finos de sílica, 2004.103f. Dissertação (Mestrado em Tecnologia Nuclear - Materiais). Instituto de Pesquisas Energéticas e Nucleares, São Paulo. 
[36] MARÇAL, R. L. S. B., Fabricação de vidros especiais a partir de resíduos de corte e polimento da indústria de rochas ornamentais. 2011. Dissertação (Mestrado em Ciências - Ciências dos Materiais). Instituto Militar de Engenharia, Rio de Janeiro.

[37] INTERNATIONAL ORGANIZATION FOR STANDARTIZATION. Glass Resistance to attack by a boiling aqueus solution of mixed álcali Method of test and classification. Geneve Switzerland, 1991. (695-1984 (E))

[38] CARTER C. B.; NORTON, M. G. Ceramic Materials Sicience and Engineering. $1^{\text {a }}$ ed. Sinpringer: 2007.

[39] CULLIT B. D. Elements of X-Ray Difraction. $2^{2}$ ed. Addision-Wesley Publishing Company: 1978.

[40] PADILHA, A. F.; AMBROZIO FH, F. Técnicas de análise microestrutural. 1aㅗㄴ ed. Hermus Editora Limitada: 1985.

[41] GOODNEY, P. J. Electron microscopy and analysis. Londres. Wykeham Publications: 1975.

[42] BARSOUM, M. W. Fundamentals of Ceramics. IOP Publishing Ltd: 2003.

[43] INTERNATIONAL COMMISSION ON ILLUMINATION. CIE System. Disponível em <http://cie.co.at/>. Acesso em: maio de 2015.

[44] ROTH, S. R. NEGAS, T. CONN. L. P. Phase Diagrams for Ceramists. The American Ceramic Society,

[45] DELLA V P., KUHN I., HOTZA D. Reciclagem de resíduos agro-industriais: cinza de casca de arroz como fonte alternativa de sílica. Cerâmica Industrial, v.10, p. 22-25, 2005. 
[46] SERRANO, Antonio G. S., Incorporação de Cinzas de Casca de Arroz em argila vermelha. 2012. Trabalho de conclusão de curso (Tecnologia dos Materiais Materiais Cerâmicos), Faculdade de Tecnologia de São Paulo, São Paulo.

[47] ISMAIL, S. A., EZZ-ELDIN, F. M. Corrosion behaviour of vitrified rice husk ash. European Journal of Glass Science and Technology, v. 45, p. 220-226, 2004.

[48] ESCARDINO, A. ET AL. Utilizing the used catalyst from refinery fcc units as a substitute for kaolin in formulating ceramics frits, Waste Management \& Research, v. 13, p. 569-578, 1995.

[49] MOTA, Cláudio J. A., Química e tecnologia para o desenvolvimento, aplicações e necessidades da petrobrás à produção de gasolina. Química Nova, v. 18, p. 203-209, 1994.

[50] DELBIANCO, Gislaine Aparecida Barana. Propriedades físico-químicas de vidrados cerâmicos preparados com rejeitos galvânicos atuando como corantes. 2003. xv, 82 f. Dissertação (mestrado) - Universidade Estadual Paulista, Instituto de Geociências e Ciências Exatas. 